\title{
DIAGNOSING CONSUMER CONFUSION AND SUB-OPTIMAL SHOPPING EFFORT: THEORY AND MORTGAGE-MARKET EVIDENCE
}

\author{
Susan E. Woodward \\ Robert E. Hall \\ Working Paper 16007 \\ http://www.nber.org/papers/w16007
NATIONAL BUREAU OF ECONOMIC RESEARCH
1050 Massachusetts Avenue
Cambridge, MA 02138

May 2010

The views expressed herein are those of the authors and do not necessarily reflect the views of the National Bureau of Economic Research.

NBER working papers are circulated for discussion and comment purposes. They have not been peerreviewed or been subject to the review by the NBER Board of Directors that accompanies official NBER publications.

(C) 2010 by Susan E. Woodward and Robert E. Hall. All rights reserved. Short sections of text, not to exceed two paragraphs, may be quoted without explicit permission provided that full credit, including (C) notice, is given to the source. 
Diagnosing Consumer Confusion and Sub-Optimal Shopping Effort: Theory and Mortgage-Market Evidence

Susan E. Woodward and Robert E. Hall

NBER Working Paper No. 16007

May 2010

JEL No. D12,D18,G21

\begin{abstract}
Mortgage loans are leading examples of transactions where experts on one side of the market take advantage of consumers' lack of knowledge and experience. We study the compensation that borrowers pay to mortgage brokers for assistance from application to closing. Two findings support the conclusion that confused borrowers overpay for brokers' services: (1) A model of effective shopping shows that borrowers sacrifice at least $\$ 1,000$ by shopping from too few brokers. (2) Borrowers who compensate their brokers with both cash and a commission from the lender pay twice as much as similar borrowers who pay no cash.
\end{abstract}

Susan E. Woodward

Sand Hill Econometrics, Inc

115 Everett Ave.

Palo Alto, CA 94301

swoodward@sandhillecon.com

Robert E. Hall

Hoover Institution

Stanford University

Stanford, CA 94305-6010

and NBER

rehall@gmail.com

An online appendix is available at:

http://www.nber.org/data-appendix/w16007 


\section{Introduction}

Consumers often transact with imperfect information about the best price available for a product. Some examples are mundane - a shopper does not know the price of kleenex at every nearby store. Others are more substantial, such as the best available price for a new Ford Focus or the best expense ratio for an S\&P 500-indexed mutual fund. We study a large expenditure that the majority of consumers make only a few times in their lives, the payment for mortgage origination services. These payments range from zero to $\$ 30,000$ for mortgages of normal size. The payments are described as "origination fees," "points," and a myriad of other terms; frequently the borrower pays for a dozen or more different categories of origination services. On average among the loans we study, about half of the value that the borrower transfers to the broker takes the form of a payment by the wholesale lender to the mortgage broker. The borrower bears the burden of this part of the payment in the form of a higher interest rate on the loan.

These payments are compensation to mortgage brokers for their services in arranging the origination of a mortgage. Because consumers enter the mortgage market infrequently and because of features of the market that make it difficult to learn the best price, mortgage origination pricing is a leading example of a market where one suspects that many consumers pay well above the best price. Our results confirm this suspicion strongly.

We stress that this paper is about how much borrowers pay their brokers for origination services. The broker is an administrator of the process of loan origination. The broker bears none of the risk of default on the mortgage, so that risk is not a determinant of the broker's compensation.

We reach our conclusion by studying the distribution of origination charges for a large sample of mortgages involving brokers, where federally mandated disclosure documents report the entire amount of the broker's revenue, including both the total charges imposed on the borrower and the additional amount the lender pays the broker. We consider a minimal shopping strategy that borrowers might pursue in trying to find the best price - getting quotes from two brokers, asking the one with the higher proposed price to beat the lower price of the opponent, and continuing this process until one broker is unwilling to improve on the other's best proposal. This process is an English auction, in which the lower-cost broker gets the business and the charge equals the cost of the losing broker, according to standard auction principles.

It's a standard statistical exercise to find the distribution of a variable from the distribution of the larger of a pair of draws from the variable. We perform that exercise to calculate the distribution of broker cost. We find that the implied cost is generally quite high, but more important, the upper tail of the cost distribution is thick - a significant fraction of mortgages appear to cost the broker more than $\$ 5,000$ to originate. When we repeat the 
exercise for shopping among three and four brokers, we find that the implied distribution of cost is completely implausible, with an even larger fraction implied to cost more than $\$ 5,000$. The distribution has an implausible shape as well. We conclude that among our shopping models, only the one where borrowers shop from just a pair of brokers is close to reasonable. Our conclusion that borrowers consider no more than two mortgages draws support from surveys of borrower behavior as well.

Given this conclusion, we ask what benefit a borrower who shopped from only two brokers passed up by not shopping from three or four. The answers are so large that we believe that many of the borrowers must have been unaware of the likely benefits of more shopping. For example, for a mortgage with $\$ 100,000$ principal, a borrower would save a median of $\$ 981$ by adding one more broker to the mix and $\$ 1,393$ by adding two. And with $\$ 200,000$ principal, the savings are $\$ 1,866$ and $\$ 2,664$. Because we do not believe that borrowers would intentionally pass up such large benefits just to avoid talking to another broker, we conclude that confusion about how this market works caused borrowers to shop too little.

Our second approach to studying confusion among mortgage borrowers is to compare (1) the total closing charges for loans where the borrower pays a higher interest rate to fund the closing charge to (2) the total charges for loans where the borrower pays all of those charges in cash. The first group pays somewhat lower total charges than the second, but the important finding is that both those groups pay far less than borrowers who use both types of funding in roughly equal proportion. This evidence is consistent with the hypothesis that borrowers treat the two charges independently, failing to recognize that a borrower who pays more cash is entitled to a lower interest rate and vice versa.

Earlier research has shown that mortgage charges are higher for less-educated borrowers, members of minorities, borrowers who pay high interest rates, and those who borrow larger principal amounts - we review that research in the Appendix. We confirm these findings. The research has not shown whether the borrowers paying higher charges did so because arranging the mortgage broker's cost was higher or because those borrowers suffered exploitation due to their lack of knowledge of the best available charge, which should be little higher than cost. Our results show that large fractions of the higher charges are the result of limited shopping rather than higher cost.

Our data come from a sample of mortgages insured by the Federal Housing Administration (FHA) during a six-week period in 2001. The FHA insures mortgages of fairly creditworthy borrowers for modestly priced houses, up to loan limits that vary by geography. The data report the amount that the borrower paid for mortgage-related charges at the closing, the principal amount that the lender paid into the closing, the yield-spread premium, and the interest rate for the mortgage. All of these loans are 30-year fixed-rate mortgages for the purchase of a house.

Our econometric approach is mainly non-parametric. We represent the full distribution 
of closing charges in terms of 299 quantiles, conditional on observed borrower and loan characteristics. From the quantiles, we make calculations of the distribution of broker cost and of the charges that borrowers would have paid under more effective shopping strategies. We provide bootstrap standard errors for all of our calculations.

\section{Economics of Mortgage Originations}

A mortgage is a loan secured by a house. The typical mortgage provides for monthly payments over a term of 30 years. The amount of the loan, called the loan principal, transfers to the seller of the house at the moment when the borrower takes ownership of the house, called the loan closing. Our FHA sample contains only 30-year fixed-rate mortgages for the purchase of a home; there are no investor loans and no refinancings among them. The borrower's coupon rate is applied to the principal amount of the loan to calculate the borrower's monthly payment. The loans are fully amortizing, so there is no final repayment of principal, in contrast to the typical bond. The borrower has the option to pay off a mortgage before 30 years, subject to a pre-payment penalty, which is limited by law in all states. Because borrowers sometimes move, change houses, extract appreciated equity, and take advantage of lower interest rates to refinance, most mortgages pre-pay prior to their 30-year maturity. Nonetheless, roughly 30 percent of owner-occupied homes have no mortgage, and nearly all got to this state by paying off a 30-year loan-see U.S. Census Department (2001).

\subsection{Brokers and the yield-spread premium}

Mortgage brokers perform the service of originating a mortgage. A broker matches a borrower with a wholesale lender. The broker is not a party to the resulting financial contract between borrower and lender and thus bears none of the default risk of the mortgage. The broker helps the borrower prepare an application and arranges for the services of one or more appraisers and of an agent to close the transaction. The broker serves lenders by finding potential borrowers and helping them complete the necessary paperwork. Most large lenders have retail origination operations and also use brokers as originating agents. A broker usually deals with a number of wholesale lenders.

The borrower deals with a broker under conditions comparable to a purchaser dealing with a retailer of an expensive item. Like the retailer and purchaser, the broker and borrower negotiate the terms of the transaction without participation from the upstream wholesaler. The wholesaler provides funds for the loan under quoted terms. The borrower receives a specified amount of cash, the principal amount of the mortgage, delivered by the lender at the time of the closing, in exchange for a mortgage at an interest rate resulting from the negotiation. The borrower may also pay the broker a negotiated amount at the closing; we 
call this the cash closing charge. Berndt, Hollifield and Sandås (2009) discuss the bargaining problem between borrower and broker in the framework of the Nash bargain in its alternating offer form.

The broker may also receive a payment from the lender called the yield-spread premium or YSP, which is often about half of the broker's compensation. The terms offered by the wholesale lender appear in a rate sheet, a document the broker receives from the lender at least daily. The rate sheet shows the YSP the lender offers to pay the broker for originating a mortgage. The YSP is an increasing function of the coupon rate and principal amount of the loan, and decreasing in the term $(15,30,45$ or 60 days) for which the loan is locked (the length of time the broker and borrower have the option to complete the loan). The YSP rises as interest rates rise, but at a decreasing rate because higher rate loans are more likely to prepay than lower rate loans, so higher rates are generally earned for shorter periods. This function is determined by expectations about movements in interest rates in the competitive wholesale mortgage market and the refinancing choices of borrowers. We take it as given.

The following example, representative of the transactions in our data, illustrates the operation of the YSP: A borrower pays her broker $\$ 1,500$ as a cash closing payment. In addition, the lender pays the broker a YSP of $\$ 2,300$. The broker's all-in cost, mainly the value of his time, is $\$ 2,400$. The borrower has paid $\$ 1,500+\$ 2,300=\$ 3,800$ in closing charges for a loan when she could have pressed the broker to do the loan for close to $\$ 2,400$. A savvy borrower could have insisted that the broker charge her only $\$ 100$ in cash, which, together with the yield-spread premium of $\$ 2,300$, would have just covered his cost of $\$ 2,400$.

Figure 1 shows an example of an actual rate sheet. The figures show the amount that the lender will deliver at closing on behalf of the borrower (always taken to be 100) plus the premium to be paid to the broker, such as 2.25 percent of the principal for a loan at a coupon rate of $87 / 8$ percent with a lock period of 30 days. Notice that below the solid line, the YSP becomes negative. For loans at these low interest rates, the borrower (not the broker) pays the specified amount of cash into the closing to make up the difference.

The coupon rate that corresponds to a zero YSP is called the par rate and is a useful benchmark of mortgage interest rates. It corresponds to the row in the figure just below the solid line.

\subsection{Bargaining over mortgage terms}

In this subsection, we explore the simple view that the borrower and the mortgage broker make a bargain that maximizes their joint surplus. We let $r$ be the coupon rate on the mortgage, $p(r)$ be the payment at annual rate for a 30-year amortized fixed-rate mortgage at coupon rate $r, r_{b}$ be the borrower's personal discount rate, $Y(r)$ be the yield-spread premium available from wholesale lenders, per dollar of principal, $L$ be the cash closing charge the 


\begin{tabular}{crrrr}
\hline \multirow{2}{*}{ Rate } & \multicolumn{4}{c}{ Lock period } \\
\cline { 2 - 5 } & 15 days & 30 days & 45 days & 60 days \\
\hline $\mathbf{9 . 1 2 5} \%$ & 103.375 & 103.250 & 103.125 & 103.000 \\
$\mathbf{9 . 0 0 0 \%}$ & 103.000 & 102.875 & 102.750 & 102.625 \\
$\mathbf{8 . 8 7 5 \%}$ & 102.625 & 102.500 & 102.375 & 102.250 \\
$\mathbf{8 . 7 5 0} \%$ & 102.375 & 102.250 & 102.125 & 102.000 \\
$\mathbf{8 . 6 2 5 \%}$ & 102.000 & 101.875 & 101.750 & 101.625 \\
$\mathbf{8 . 5 0 0 \%}$ & 101.500 & 101.375 & 101.250 & 101.125 \\
$\mathbf{8 . 3 7 5 \%}$ & 101.000 & 100.875 & 100.750 & 100.625 \\
$\mathbf{8 . 2 5 0} \%$ & 100.625 & 100.500 & 100.375 & 100.250 \\
\hline $\mathbf{8 . 1 2 5 \%}$ & 100.250 & 100.125 & 100.000 & 99.875 \\
$\mathbf{8 . 0 0 0 \%}$ & 99.750 & 99.625 & 99.500 & 99.375 \\
$\mathbf{7 . 8 7 5 \%}$ & 99.125 & 99.000 & 98.875 & 98.750 \\
$\mathbf{7 . 7 5 0} \%$ & 98.625 & 98.500 & 98.375 & 98.250 \\
$\mathbf{7 . 6 2 5} \%$ & 98.250 & 98.125 & 98.000 & 97.875 \\
$\mathbf{7 . 5 0 0 \%}$ & 97.625 & 97.500 & 97.375 & 97.250 \\
\hline
\end{tabular}

Figure 1: An Actual Rate Sheet for April 2000

borrowers pays to the broker, $T^{*}$ be the time (in years) to paying off the mortgage in the mind of the borrower, $A(r, T)$ be the remaining principal on a 30-year mortgage at coupon rate $r$ as of time $T, V(r, T)$ be the present value of a $\$ 1$ per year flow lasting for $T$ years discounted at rate $r$, and $\tilde{V}(r, T)$ be the present value of $\$ 1 T$ years from now.

The borrower's net benefit of the loan, per dollar of principal, is

$$
1-p(r) V\left(r_{b}, T^{*}\right)-A\left(r, T^{*}\right) \tilde{V}\left(r, T^{*}\right)-L .
$$

The first term is the benefit of the principal supplied by the lender, the second is the present value of the loan payments, the third is the present value of the payoff of the principal at $T^{*}$, and the fourth is the cash closing payment to the broker.

The broker's benefit from originating the loan, per dollar of principal, is the total closing charge less the broker's cost, $k$,

$$
Y(r)+L-k
$$

The surplus is the sum of the borrower's and broker's benefits,

$$
1-p(r) V\left(r_{b}, T^{*}\right)-A\left(r, T^{*}\right) \tilde{V}\left(r, T^{*}\right)+Y(r)-k
$$

The cash closing charge, $L$, drops out of the sum, so it does not appear in the rest of the discussion. In terms of an Edgeworth-box analysis of this bargaining problem, the maximization of the surplus places the parties on their contract curve and the choice of $L$ 
picks a point on the contract curve. Maximization of the surplus is a matter of choosing the coupon rate $r$ or, equivalently, choosing the YSP, $Y(r)$.

Lenders solve a complicated problem in setting the rate sheets that determine the YSP as a function of the coupon rate, $Y(r)$. The central factor is that a higher coupon rate implies a higher present value of the payments, a benefit that the broker shares through the YSP. One important subsidiary factor is the likelihood of early payoff of the mortgage from the sale of the house or refinancing. Payoffs tend to occur earlier for high-rate mortgages, a factor the lender builds into the curvature of the YSP as a function of the coupon rate. Because the present value of the payments on lower-coupon loans falls short of the amount of the principal, the YSP will be negative below some coupon rate. Lenders also consider any market power they may have in the wholesale market, though we believe this factor is not very important-brokers know the quoted terms of numerous lenders every day for identical mortgages, so the wholesale market has close to perfect Bertrand competition. Lenders adjust their YSPs daily or even more often to modulate their lending flows and reflect changes in market rates.

Our best source of information about the YSP is a group of rate sheets from a dozen large lenders for May 31, 2000. Figure 2 gives averages for May 31, 2000, for a 30-day lock period, with a cost to the broker, $k=\$ 2500$, which we believe is reasonable. The error bars are one standard error - they become larger at both ends of the line because fewer lenders quoted premiums so far from the popular interest rates. The figure shows the benefit of the loan to a hypothetical borrower with a discount rate of 9 percent per year, from equation (1). The benefits are based on a time to payoff of $T^{*}=7$ years, which we believe is typical.

Figure 2 shows how the joint surplus varies with the coupon interest rate. For the case shown, it is clear that the efficient loan would have the lowest interest rate the lender offers and thus the most negative YSP. The YSPs lenders offer plainly undercompensates a borrower for the higher payment of a loan with a positive YSP, if the borrower's discount rate is not too much higher than the coupon rate. A borrower who had enough cash in an investment of equal risk to a mortgage, paying less than 10 percent per year, could use cash withdrawn from that account to induce a broker to originate a loan with a large negative YSP and come out ahead - the interest rate implicit in the YSP, under the assumptions of these calculations, is higher than 10 percent. If the borrower expects to repay the loan in much less than seven years, the opposite conclusion follows; the maximum surplus occurs with a large YSP and no cash closing charge.

Figure 3 considers the relation between the coupon rate and the joint surplus for borrowers at three coupon rates, with expected time to payoff of 7 years. At the bottom is the same surplus as in Figure 2. This borrower gains relatively little from the loan transaction, given that the borrower's discount rate is close to the rate of a mortgage that has zero YSP. This borrower-broker pair is best off by choosing the lowest available coupon interest rate offered 


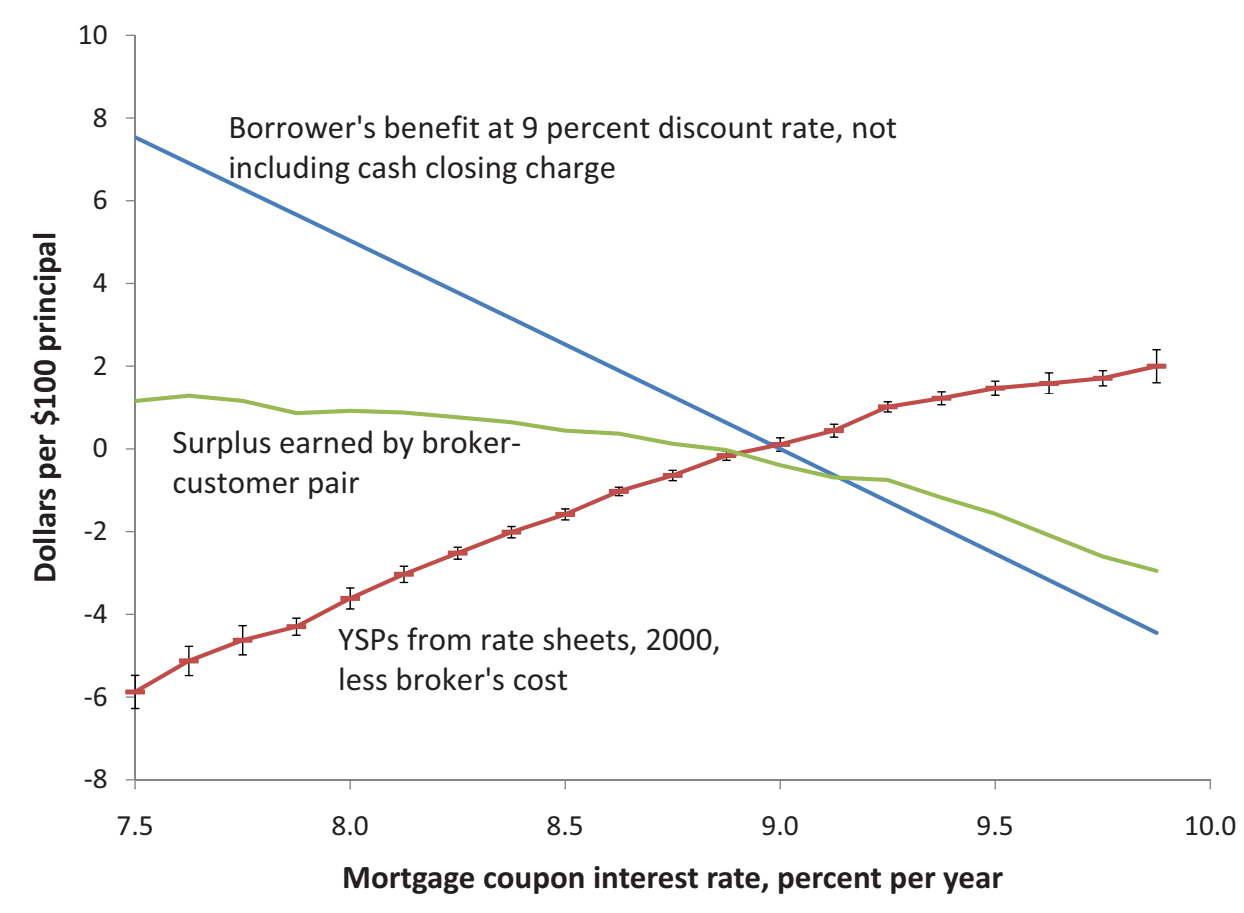

Figure 2: The Yield-Spread Premium on May 31, 2000, Borrower's Benefit, and the Joint Surplus

by the lender and using some of the resulting benefit to the borrower to pay the lender the corresponding negative YSP.

The middle line in Figure 3 shows the surplus to the pairing of a broker with a borrower whose discount rate is 15 percent. The surplus is substantial-because the discounted cost to the borrower of repaying the loan is less than the principal- but is essentially flat across the interest rates. Thus the provisions of the rate sheet achieve close to indifference in this case, with the loan expected to last for 7 years and the borrower's discount rate somewhat above the par rate. The top line in the figure shows that, when the borrower has a discount rate of 20 percent, the surplus is even higher and reaches a vaguely defined maximum at 8 $5 / 8$ percent.

Figure 4 shows the same three lines for borrowers who plan to pay the loan off in 4 years. In these cases, the surplus rises with the interest rates to maximums at $91 / 4$ percent for the low-discount borrower and $91 / 2$ percent for the two higher-discount borrowers. It pays the broker-borrower pair to take advantage of the higher YSP that goes with the higher coupon rate, because the borrower only pays the higher rate for 4 years.

The basic message of the investigation of the joint surplus as a function of the interest rate and resulting YSP is that lenders offer YSP schedules in their rate sheets that make the broker-borrower pair close to indifferent to the interest rate if they plan to pay the loan off in seven years. No compelling economic force tells the pair what rate to pick in that case. Our data show fairly wide dispersion across rate categories, consistent with the lack of such 


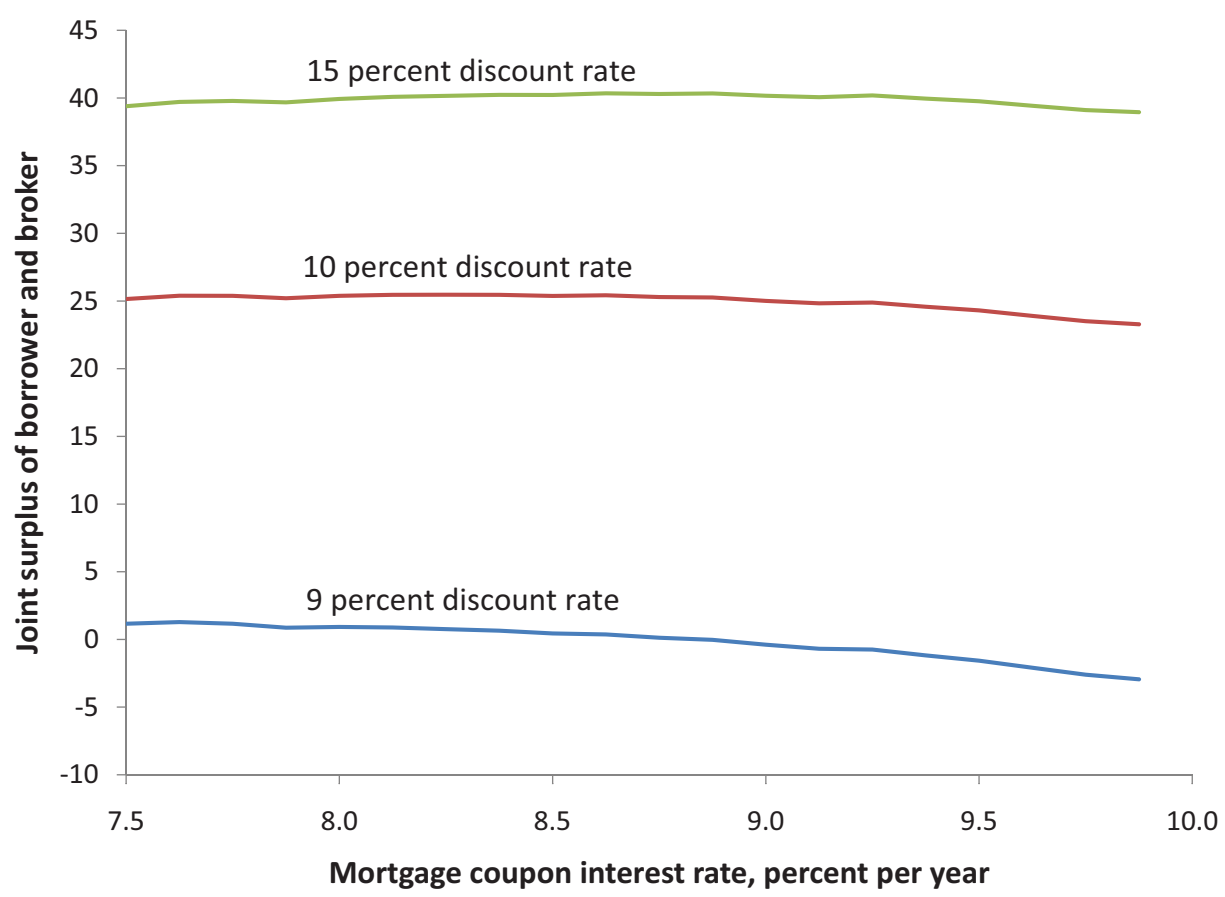

Figure 3: Joint Surplus of Borrower and Broker for Three Borrower Discount Rates, 7-Year Expected Mortgage Life

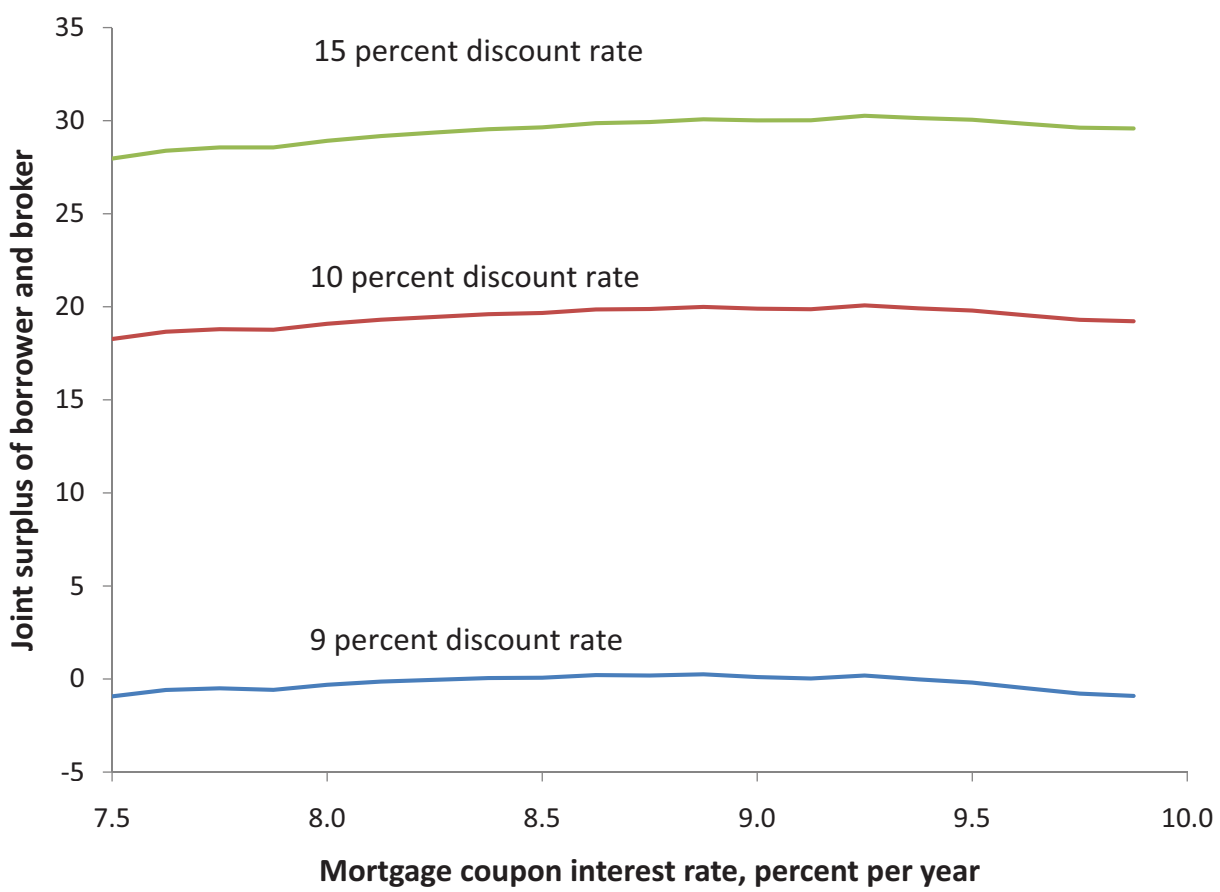

Figure 4: Joint Surplus of Borrower and Broker for Three Borrower Discount Rates, 4-Year Expected Mortgage Life 
a compelling force. Maximization of the joint surplus would push the terms toward higher YSPs and lower cash closing charges if the borrower expects to repay in less than seven years or has an unusually high discount rate.

The YSP lets the home-buyer borrow the funds to compensate the broker, provided the borrower can qualify for a higher interest rate. The value flowing from the borrower to the broker is the cash closing charges plus the YSP. For the broker, the mix of the two components is immaterial, as the broker receives both the cash closing charge and the YSP as cash at the same time. A borrower who is cash-constrained and knows she is likely to pay off the mortgage fairly soon will see the cost of the borrowed component resulting from a higher interest as less than what the broker receives as YSP, so their efficient bargain should pay the broker entirely with the YSP and the closing charge should be zero (or even negative, which occurs in a small fraction of our sample). Similarly, a borrower with a low discount rate (and or expecting to be in the house for a long time) may see the cost of the borrowed component as greater than the YSP and then the efficient deal with the broker will not involve borrowing any of the broker's compensation; rather, the borrower will pay it in cash, and even pay a negative YSP to lower the interest rate further.

\subsection{Potential consumer confusion}

Our predictions about the efficient deal between borrower and broker rest on the assumption that the borrower is able to recognize that she is paying a higher interest rate and thus creating value that could be used to pay the broker in place of a cash closing charge. An alternative model holds that some borrowers are unable to spot when an interest rate is high enough to deserve a reduction in the closing charge and thus wind up paying both normal closing charges and giving the brokers handsome YSPs as well. The value-maximizing broker will try to keep borrowers uninformed about the availability of mortgages at lower interest rates, in the hope of earning high compensation from both components.

The borrower's information about the mortgage market is often incomplete. For mortgages on newly purchased homes, the buyer's real-estate broker often refers the purchaser to a mortgage broker, who explains that he has access to mortgages from dozens of competing lenders and that he can help the borrower choose the one with the best terms. He does not mention that each of these lenders offers a link between the interest rate and the YSP that he will receive. He proposes one or more mortgages, each with a rate that includes as big a YSP as he thinks the borrower will accept. He pairs the rate proposal with a proposal for a cash closing charge. His judgment on this question will turn on how careful and informed a shopper he believes the borrower is.

Mortgage law requires that the broker provide the borrower at this stage in the process a good-faith estimate of the closing charge, but not of the YSP. Thus the borrower does not 
know prior to making a deal with a mortgage broker how much the broker will earn in total fees. The borrower may eventually learn the amount of the YSP, in principle, because the law requires its disclosure at the time of the closing, on the HUD-1 form that is part of the closing document package. The terminology of the disclosure and the location of the YSP entry on the form may inhibit many borrowers from understanding the YSP, and, in any case, the information arrives long after the mortgage deal is made.

\subsection{Points}

One important source of confusion among borrowers is the labeling of parts of cash closing charges as "points." A point is a component of the broker's closing charge calculated as a percent of the principal amount of the loan. From the perspective of the economics of a mortgage origination, a charge for points is just part of the total that the borrower pays to the broker. Borrowers may believe that paying points "buys down" the interest rate. In principle, this should be true. If a broker receives part of his cash closing charge as points, just as in any other form, the borrower should be able to bargain for a lower YSP and thus a lower interest rate. But this only happens if the borrower uses the added bargaining power that paying more cash to the broker ought to give the borrower. Nothing stops the broker from offering an interest rate that earns him a handsome YSP and also including a charge

for points as part of the pricing of the origination. In our sample, charges for points on loans were present on roughly 30 percent of the loans with positive YSPs.

When the coupon rate is sufficiently low that the YSP is negative, the borrower will face a charge for points that goes to the lender. If the charge for points is the amount on the rate sheet for the negative YSP (below the horizontal line in Figure 1), the charge genuinely brings a lower interest rate. But here too, the broker may charge more for points than the lender receives - nothing stops the broker from charging more for the negative YSP than appears on the rate sheet and keeping the excess as part of his own compensation.

The borrower's understanding of the cash closing charge may also be limited by the practice of dividing the charge into many elements. Figure 5 is an example containing terms found frequently in our data on mortgages. The good-faith disclosure form prevailing when these loans were written did not require brokers to state the sum of the charges (new rules do require disclosure of the sum), so comparison of loans was challenging. Some of the challenge remains, because the disclosure law perversely allows for points to be separated from other closing charges, suggesting that even the regulators fail to understand that points are just another name for broker or lender charges. Borrowers may not recognize that only the sum - including points - is meaningful. Lacko and Pappalardo (2007) found that few borrowers had any idea what the term "discount points" means, and worse, that one-third believed it was a discount they were receiving instead of an amount they were paying. 


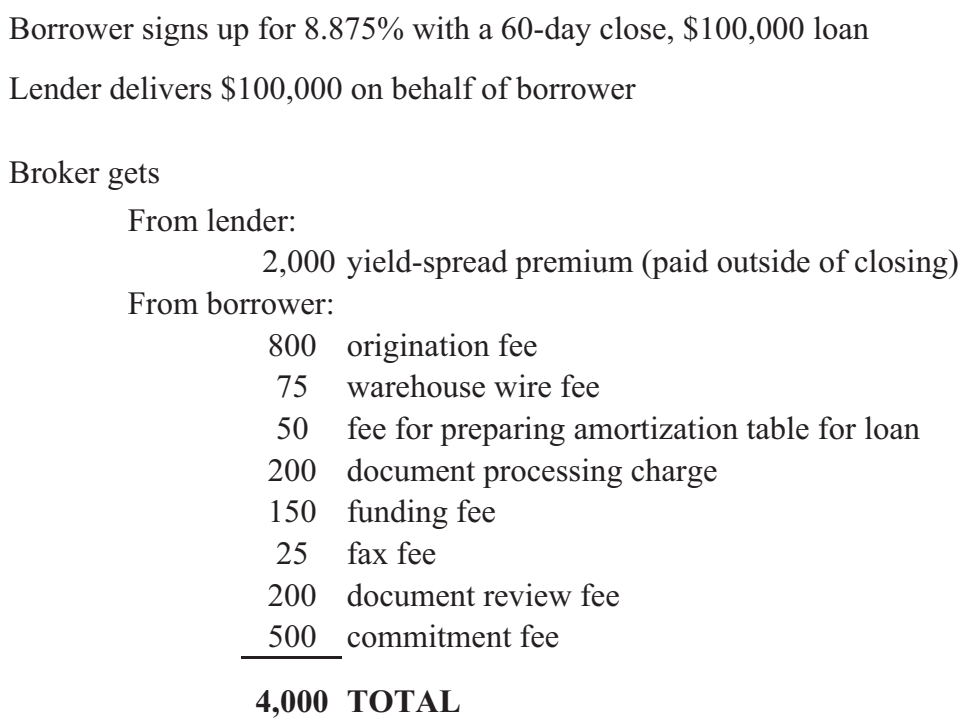

Figure 5: Example of a loan transaction

\subsection{Industrial organization analysis of mortgage brokerage}

Our findings later in the paper demonstrate that an important fraction of borrowers leave a lot of money on the table for their brokers. As we demonstrate later in the paper, the upper tail of the distribution of origination charges brokers receive contains some astonishingly large values. We use the term margin to mean the difference between the revenue from originating a mortgage and the cost of executing the transaction. Here we include only costs incurred after the broker meets the borrower and strikes a deal. The margin is the amount at issue when the broker bargains with the borrower over the charge. Thus we believe that mortgage brokers earn substantial margins from many but not all of their origination efforts.

Mortgage brokerage involves only small out-of-pocket costs for the broker. A mortgage broker does not usually outsource any of the origination process to other professionals. Further, though charges labeled "origination fee," "funding fee," and "commitment fee" sound as if they flowed through to the lender, they remain firmly in the broker's pocket. Thus the costs we have in mind are largely the value of the broker's time.

The equilibrium we describe is inefficient. We do not believe that mortgage brokers earn any important rents from their origination activities. Entry to mortgage brokerage is close to free. Most states license mortgage brokers or require them to have licenses as real-estate agents, but these licenses are not difficult to obtain. Mortgage brokers dissipate the anticipated margin from originating mortgages for borrowers who fail to shop carefully by spending effort and other resources trying to find these customers. Because borrowers seldom seek out several brokers to compete for the borrower's business, brokers have to work hard to find brokerage customers. In Lacko and Pappalardo (2007), the modal number of loans considered by borrowers was two. In Federal Reserve Board (2009), more than half of 
all borrowers looked seriously at only one loan.

We noted earlier that mortgage brokers often receive referrals from real-estate brokers and that it appears that many borrowers accept a proposal from such a mortgage broker without further shopping. Hence the referrals are valuable and mortgage brokers cultivate real-estate brokers hoping to receive their referrals. Federal law - the Real Estate Settlement Practices Act-prohibits mortgage brokers from paying referral fees, but little is known about the effectiveness or enforcement of that prohibition. In any case, we believe that the mortgagebrokerage business is generally in a zero-profit equilibrium, where a new entrant perceives zero net payoff, given the costs of finding prospective customers. But once found, some of the customers are very profitable. The resources dissipated by brokers in their search for overpaying customers is, from a social point of view, mostly economic waste.

\section{Data and Data Description Model}

\subsection{Description of the FHA data}

Table 1 describes the relevant variables in our sample of 1,525 FHA brokered loans. We excluded loans with rates below 7 percent and those with interest rates not at $1 / 8$ point ticks as presumptively subsidized. Interest rates are fairly tightly clustered around $71 / 2$ percent. All the loans were made at essentially the same time, so the variation arises in the cross section of borrowers and not from changes in credit markets. The total closing charges - cash closing charge plus yield-spread premium - average $\$ 4,111$, but have substantial dispersion. The cash component is typically a little under half of the total charge and the YSP a little more than half. The principal is generally around $\$ 100,000$ and rarely exceeds $\$ 200,000$. The average credit score of the borrower is 659 , which is just below the median of the national distribution of scores. The fractions of the borrowers who are members of minorities are close to the U.S. average in the population, at 11 percent African-American and 14 percent Latino. The last statistic is the fraction of the adult population in the borrower's census tract who hold a BA degree - its average level is 21 percent. We have no measure of the education of individual borrowers, but are able to measure the education of their neighbors because we know the addresses of the borrowers.

Table 2 shows the distribution of the loans by interest rate. The $71 / 2$ percent loan is by far the most popular.

\subsection{The yield-spread premium}

As we discussed in the previous section, the YSP is a payment from the wholesale lender to the broker based on the coupon rate for the mortgage and on the amount of the principal. The lender pays the premium to the broker outside the closing. Earlier we reviewed what 


\begin{tabular}{lcc}
\hline \hline & Mean & $\begin{array}{c}\text { Standard } \\
\text { deviation }\end{array}$ \\
\hline Total closing charge, dollars & 4,111 & 2,291 \\
Percent of closing cost paid in cash & 40 & 42 \\
Principal, dollars & 112,907 & 39,891 \\
Credit score & 659 & 63 \\
Percent African-American & 11 & 12 \\
Percent Latino & 14 & \\
Percent of neighbors with BA degrees & 21 & \\
\hline Number of loans & 1525 & \\
\hline \hline
\end{tabular}

Table 1: Descriptive Statistics for Brokered Loans

\begin{tabular}{cc}
\hline \hline Interest rate & Percent of sample \\
\hline 7 & 15.0 \\
$71 / 8$ to $73 / 8$ & 22.5 \\
$71 / 2$ & 38.8 \\
$75 / 8$ to $77 / 8$ & 12.5 \\
8 and higher & 11.2 \\
\hline \hline
\end{tabular}

Table 2: Frequency Distribution of Interest Rates 


\begin{tabular}{cccc}
\hline \hline $\begin{array}{c}\text { Interest rate in } \\
\text { category, } \\
\text { percent }\end{array}$ & $\begin{array}{c}\text { Average rate in } \\
\text { category, } \\
\text { percent }\end{array}$ & $\begin{array}{c}\text { Average yield- } \\
\text { spread } \\
\text { premium per } \\
\text { \$100 principal }\end{array}$ & $\begin{array}{c}\text { Standard } \\
\text { deviation of } \\
\text { YSP ratio }\end{array}$ \\
\hline 7 to $73 / 8$ & 7.17 & 1.33 & 0.60 \\
$71 / 2$ & 7.50 & 2.32 & 0.59 \\
$75 / 8$ to $77 / 8$ & 7.78 & 2.68 & 0.83 \\
8 and higher & 8.11 & 3.18 & 1.13 \\
\hline \hline
\end{tabular}

Table 3: Average Yield-Spread Premiums in the FHA Data, by Interest Rate

we believe is highly reliable evidence about the formula for the YSP from rate sheets. Here we examine the information in the FHA data on the YSP, which provides a different view of the formula. The source of the FHA broker compensation data is the HUD-1 settlement statement, required by RESPA. This source is potentially imperfect, because there seems to be relatively little monitoring of the accuracy of a broker's disclosure and the broker may try to conceal a large premium from a borrower. Table 3 shows the average yield-spread premium for the brokered loans in our sample, by interest rate.

Figure 6 compares the relation between the coupon rate and the YSP in the FHA loans and in the rate sheets we discussed earlier. The error bars are the standard errors of the average in each category (hardly visible for the FHA data because of the large number of observations). The curve for the rate sheets lies to the right of the curve for the FHA data because mortgage rates were higher in general in 2000 than in 2001. The slope of the premium is generally lower in the FHA data. The difference in the slope could reflect changes in expectations about pre-payments and changes in the slope of the yield curve between 2000 and 2001. It could also reflect some tendency for brokers to understate their actual premiums when they are high. Because the yield-spread premiums reported in the FHA data are not obviously at odds with those in the rate sheets, and because we are unable to adjust the curve from 2000 to improve measurement of the premiums actually paid for the FHA mortgages, we will accept the reported premiums for the rest of our analysis.

Table 5 describes five cases that we use to illustrate the implications of the results of the 100. Each case perturbs the base specification along one dimension of the explanatory variables. We do not include a case for a Latino borrower because our results show little difference between African-Americans and Latinos. 


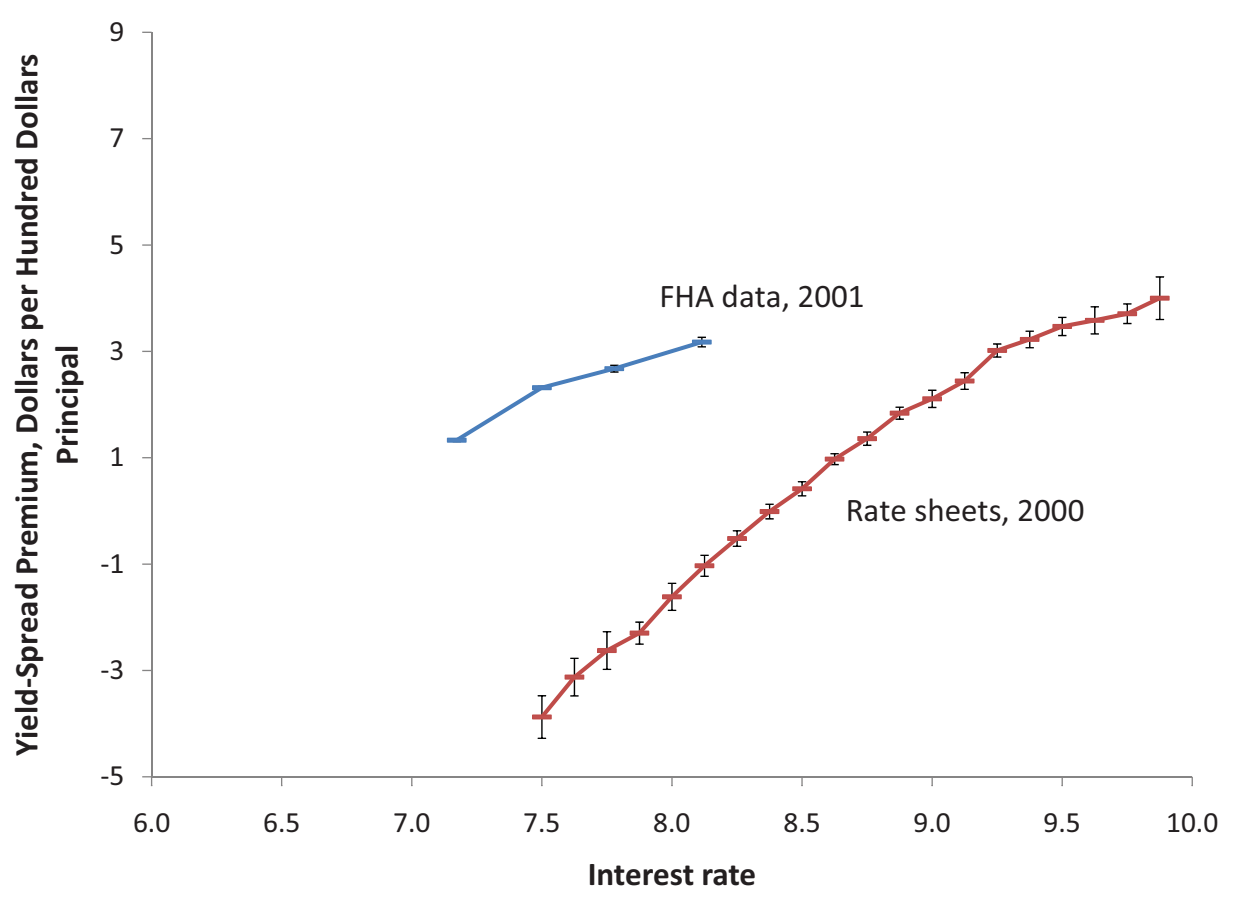

Figure 6: Comparison of Yield-Spread Premiums in FHA Loans and Lenders' Rate Sheets

\subsection{Descriptive model}

A broker receives revenue

$$
\tau=L+Y(r)
$$

from originating a mortgage at coupon rate $r$. In section 2.2, we noted that brokers are surely unconcerned about the mix between the cash from the borrower, $L$, and the cash from the lender, $Y(r)$, and that the typical borrower should be close to indifferent about the mix as well. The near-indifference suggests we should start by studying the sum.

All earlier research on mortgage terms has examined the expectation of $\tau$ or its components conditional on a vector of observed characteristics, via regression. Our interest extends to the entire distribution of $\tau$ conditional on characteristics, a vastly more complicated object than the expectation. Our approach is to estimate the quantiles $\tau_{i}(x)$ of the distribution as functions of the observed characteristics $x$. The quantile gives the value of $\tau$ such that the probability that $\tau$ is no greater than $\tau_{i}(x)$ has a designated value, $q_{i}$. It is the inverse of the cumulative distribution function $F(\tau)$ :

$$
F\left(\tau_{i}(x)\right)=q_{i},
$$

where $q_{i}$ is the designated probability for quantile $i$. We take the probability values to be: $q_{i}=i / 300$ for $i=1, \ldots, 299$. We fit the equation

$$
\tau_{i}(x)=x \beta_{i},
$$




\begin{tabular}{cc}
\hline \hline Characteristic & $\begin{array}{c}\text { Coefficient } \\
\text { (bootstrap } \\
\text { standard error) }\end{array}$ \\
\hline Intercept & 0.96 \\
Principal, hundreds of & $0.21)$ \\
thousands of dollars & 2.84 \\
African-American & $0.14)$ \\
Latino & $(0.21)$ \\
Fraction of neighbors & 0.91 \\
with BAs & $(0.15)$ \\
Credit score, hundreds & -2.51 \\
& $(0.48)$ \\
& -0.05 \\
\hline \hline
\end{tabular}

Table 4: Estimates of the Parameters of the Function Describing the Median of the Total Closing Charge

where $\beta_{i}$ is the vector of parameters describing the $i$ th percentile of the distribution of $\tau$, conditional on $x$. See Koenker and Hallock (2001) for a discussion of the estimation of quantiles. Our use of quantile estimation is only to transform the data into a form that is useful for further analysis. The transformation has the same kind of role that a Fourier transform of the data has in time-series analysis.

Table 4 shows the equation for the median $(i=150)$ of the closing charges for the mortgages in the FHA data, using the variables from Table 1. The median rises sharply with the amount of the principal. The median charge is $\$ 2,842$ higher for a mortgage with a principal of $\$ 200,000$ compared to one with a principal of $\$ 100,000$. African-American borrowers pay median closing charges that are $\$ 939$ above those of otherwise similar white borrowers and Latino borrowers pay $\$ 912$ higher more than white borrowers. Borrowers from census tracts with higher educational attainment pay smaller total closing charges - an increase of one standard deviation (12 percentage points) lowers the median cost by $\$ 300$. Finally, the borrower's credit score has a small negative relation to the median-100 extra points lowers the median charge by $\$ 55$. The last result is consistent with our observation earlier that the broker has no stake in the mortgage itself. The results in this table are similar to those found in earlier work in the regression framework. We estimated the standard errors in this and all subsequent tables by bootstrap.

Table 5 shows the definitions of five illustrative cases we carry through the rest of the paper, together with the estimated median for each case. Our base case, in the first column, is a white borrower with $\$ 100,000$ principal, living in a census tract where 21 percent of 


\begin{tabular}{|c|c|c|c|c|c|}
\hline & \multicolumn{5}{|c|}{ Case } \\
\hline & 1 & 2 & 3 & 4 & 5 \\
\hline & Base & $\begin{array}{l}\text { African- } \\
\text { American } \\
\text { borrower }\end{array}$ & $\begin{array}{c}\text { Highly } \\
\text { educated } \\
\text { neighbors }\end{array}$ & $\begin{array}{c}\text { High } \\
\text { principal }\end{array}$ & $\begin{array}{l}\text { High } \\
\text { credit } \\
\text { score }\end{array}$ \\
\hline Principal, dollars & 100,000 & 100,000 & 100,000 & 200,000 & 100,000 \\
\hline Race & White & $\begin{array}{l}\text { African- } \\
\text { American }\end{array}$ & White & White & White \\
\hline $\begin{array}{l}\text { Percent of neighbors } \\
\text { with BA degree }\end{array}$ & 21 & 21 & 45 & 21 & 21 \\
\hline Credit score & 650 & 650 & 650 & 650 & 800 \\
\hline \multirow[t]{2}{*}{$\begin{array}{l}\text { Estimated median } \\
\text { total charge, dollars }\end{array}$} & 3,194 & 4,132 & 2,592 & 6,033 & 3,111 \\
\hline & (39) & $(210)$ & $(121)$ & $(135)$ & $(132)$ \\
\hline \multirow[t]{2}{*}{$\begin{array}{l}\text { Difference from } \\
\text { base case, dollars }\end{array}$} & & 938 & -602 & 2,839 & -83 \\
\hline & & $(210)$ & $(121)$ & $(135)$ & $(132)$ \\
\hline
\end{tabular}

Table 5: Five Illustrative Cases

adults have BAs. The median total closing charge for the base case is $\$ 2,185$. The other cases involve perturbations of the variables in the equation. Note that all of the differences between the cases and the base case are statistically unambiguous, except for the high creditscore case.

Figure 7 and Figure 8 illustrate how we handle the entire distribution implied by our descriptive model, for the base case defined in Table 5. We compare the raw distribution implied by the model to a smoothed distribution that we use for subsequent analysis. The raw cumulative distribution is the graph of the percentiles on the vertical axis and the fitted values for the base case from our quantile estimates on the horizontal axis. This graph demonstrates how a set of quantile estimates describes a distribution conditional on a given point in the space of characteristics, $x$. Notice that it has small wiggles arising from sampling variation. Figure 8 shows the density constructed from the raw cumulative distribution according to the formula

$$
f\left(\tau_{i}, x\right)=\frac{0.00333}{t_{i}(x)-t_{i-1}(x)}
$$

Notice that the wiggles in the cumulative distribution turn into huge sawtooth fluctuations 


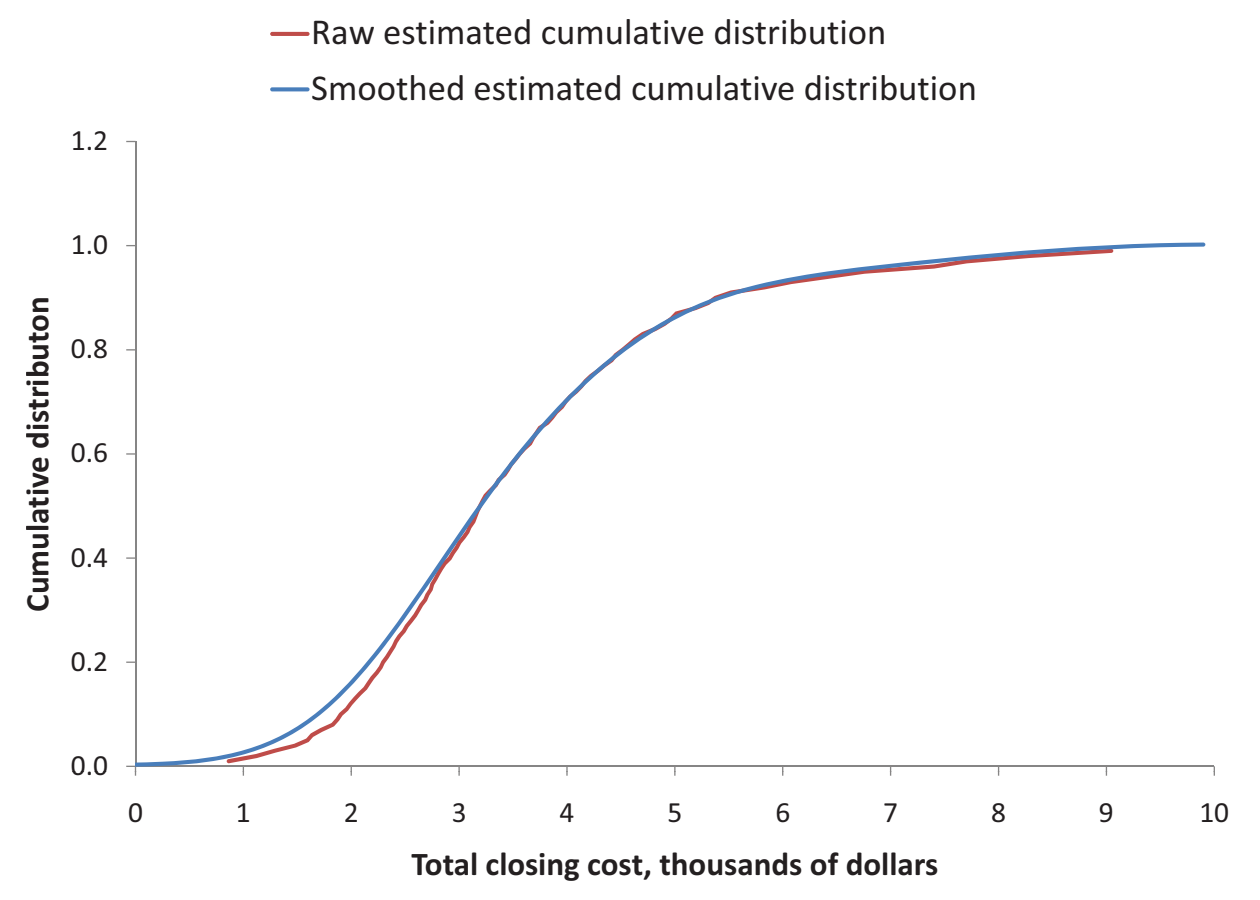

Figure 7: Raw and Smoothed Cumulative Distribution Functions for the Base Case

in the raw density. It is a well-known statistical problem that the estimate of a density at a point is not consistent. But a kernel smoother of a density is consistent. Figure 8 shows the standard kernel smoother of the raw density. Then looking back at Figure 7, one can see that applying the smoother does little to alter the shape of the cumulative distribution.

Figure 9 shows the smoothed densities that the descriptive model implies for the base case in Table 5, along with the smoothed density for the actual distribution of total closing charges in the FHA data. The model pictures the actual distribution as the mixture of the distributions conditional on the $x$-characteristics. These distributions gain their shapes almost entirely from the underlying data. Our fitted model, with $299 \times 6=1,794$ estimated coefficients, is hardly restrictive. The actual distribution has a bulge around $\$ 6,000$ relative to the distribution for the base case, reflecting the presence of loans with higher principal and other factors associated with higher total closing charges than in the base case.

Figure 10 compares the distribution for African-American borrowers to the distribution for the base case. The mode for the African-Americans is only about $\$ 700$ higher than for the white borrowers with otherwise similar characteristics in the base case, but the upper tail is much thicker for the African-Americans. Their density is more than double that of the base-case borrowers at a total closing charge of $\$ 6,000$, a great deal of money for originating a loan for $\$ 100,000$.

Figure 11 compares the distribution for borrowers having more educated neighbors to the distribution for the base case. These borrowers have a substantial advantage over those in the base case. We believe that the advantage comes mainly from the likelihood that the 


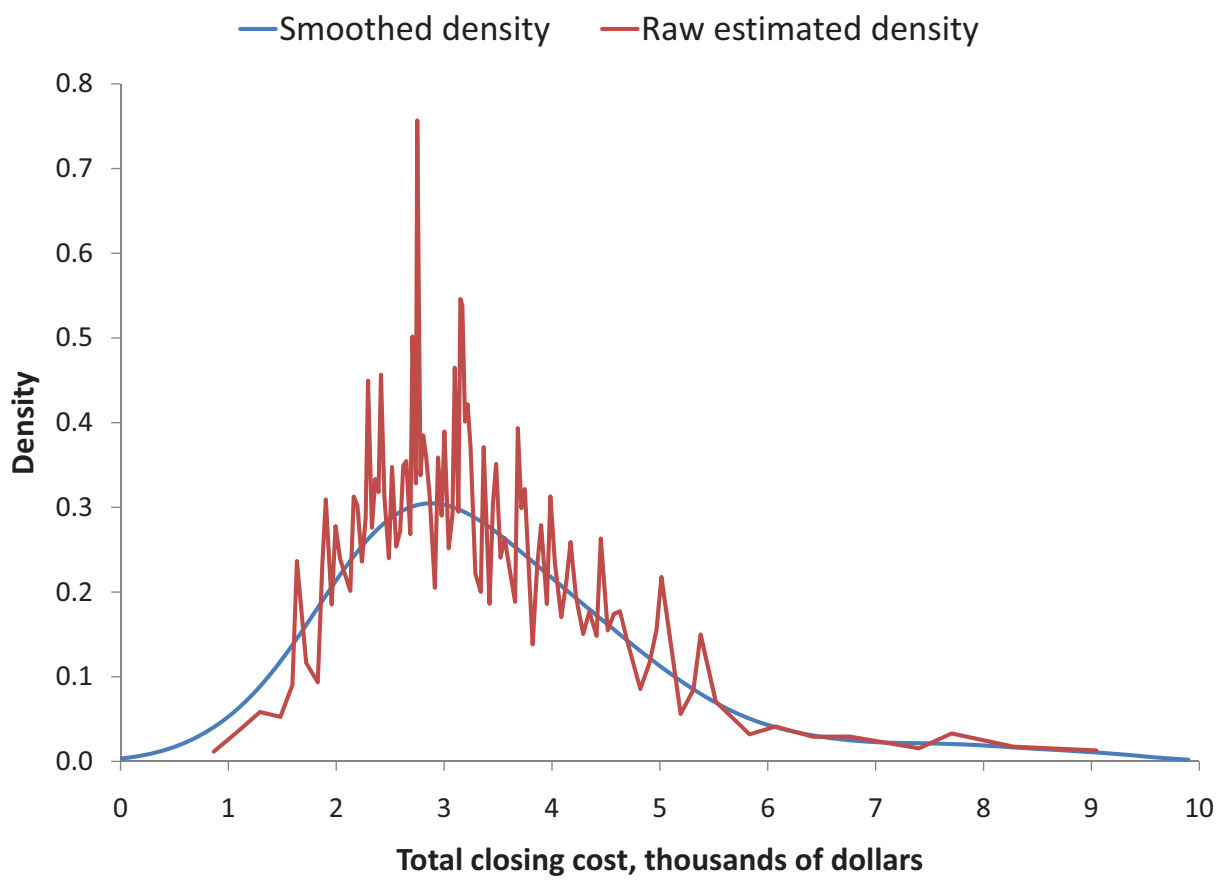

Figure 8: Raw and Smoothed Densities for the Base Case

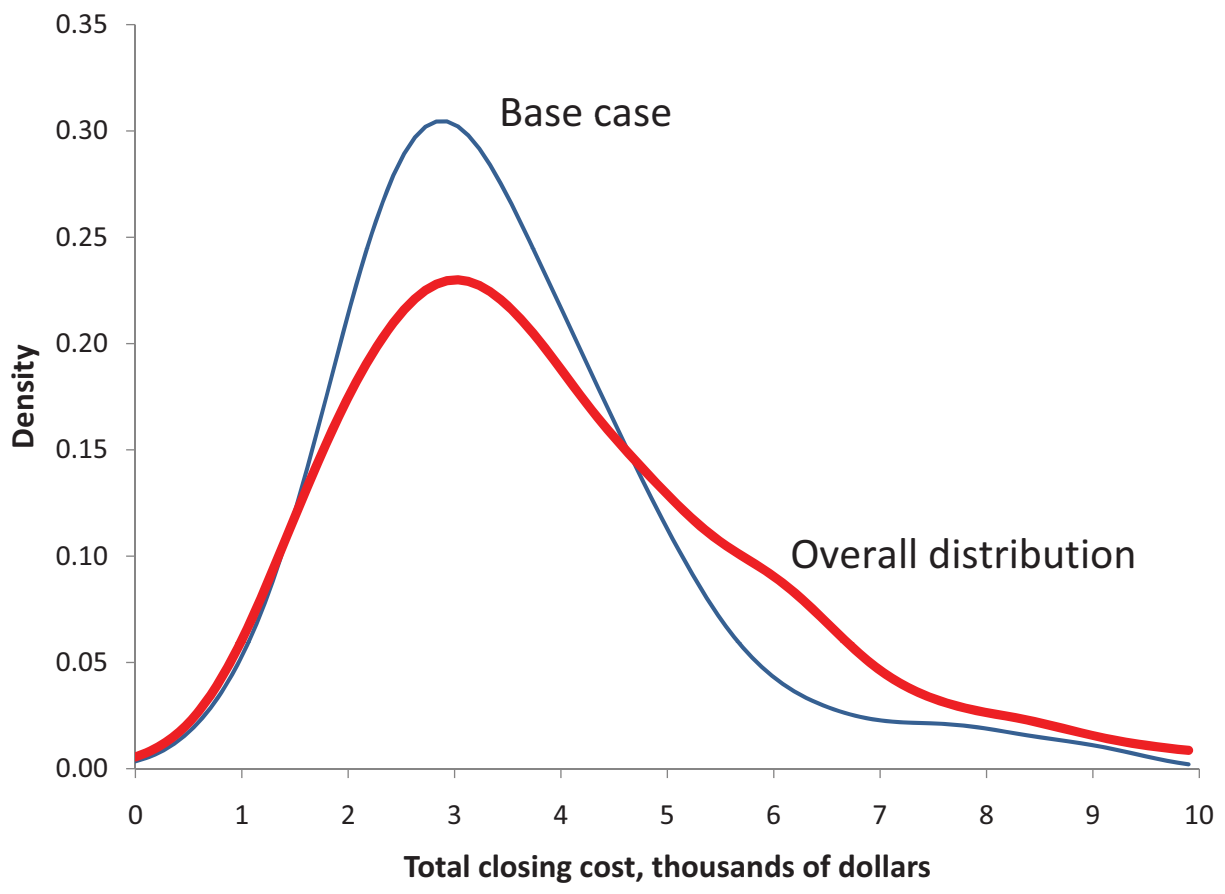

Figure 9: Smoothed Densities for the Base Case and for the Actual Closing Charge 


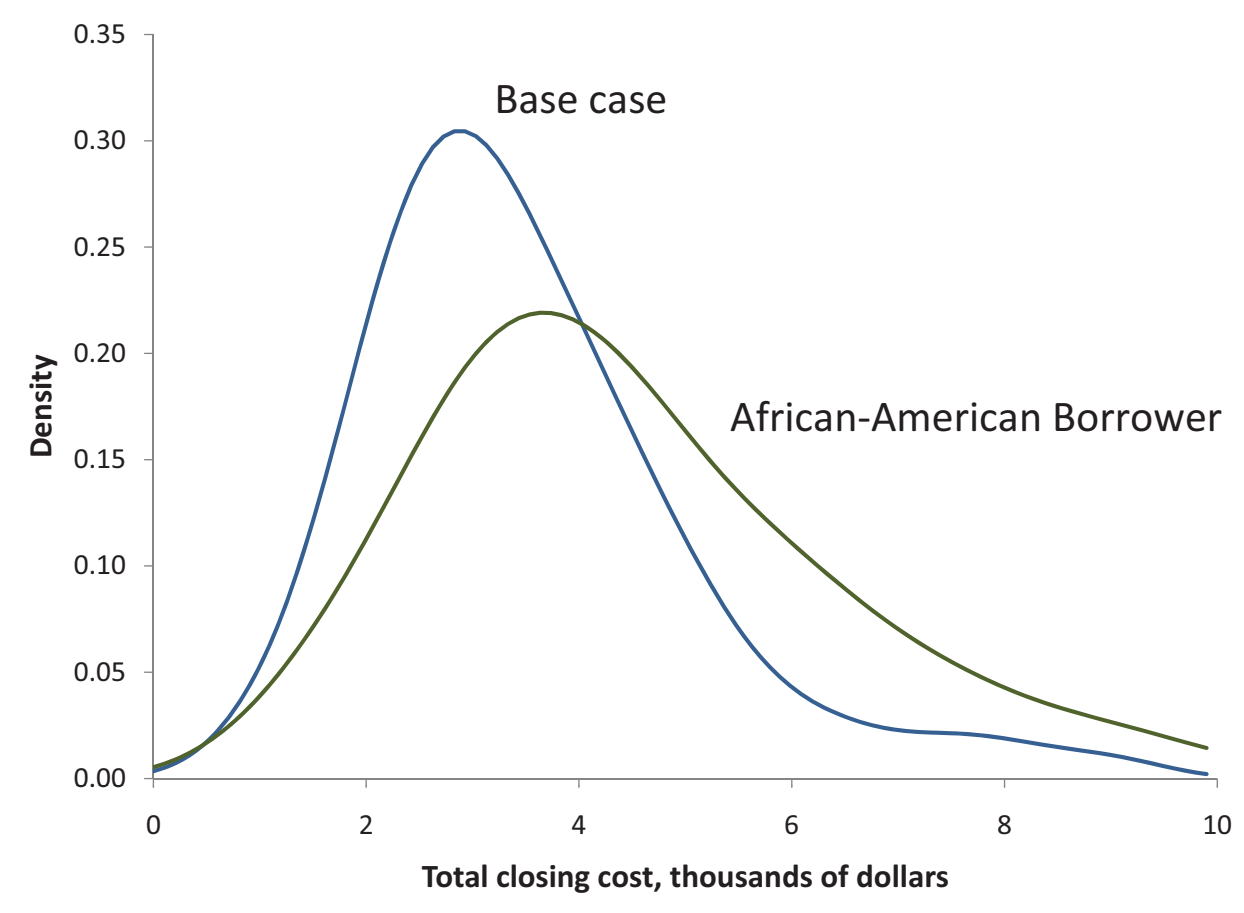

Figure 10: Smoothed Densities for the Base Case and for the Case of an Otherwise Similar African-American Borrower

borrower or a family member is better educated, but living among better-educated people may also confer an advantage because the environment contains more people who grasp the principles of shopping for a well-priced origination. The group with more educated neighbors has a very much lower density than does the base case for the range from $\$ 5,000$ to $\$ 7,000$. Even among those with educated neighbors, a significant minority pay what appear to be extreme total closing charges.

Figure 12 compares the distribution for loans with high principal $(\$ 200,000)$ to the distribution for the base case $(\$ 100,000)$. The distribution for the larger mortgages lies far to the right of the distribution for the base case. The powerful relationship with the amount of the transaction is a puzzling feature of many financial services. Little of the work of a mortgage broker scales with the amount of the principal, but the modal and median charge for a $\$ 200,000$ mortgage is about double that of a $\$ 100,000$ mortgage. The upper tail for the bigger principal is quite thick - a few people pay astronomical closing charges for the larger mortgages.

The difference between the base case and the case with a higher credit score, shown in Figure 13, is instructive. For all but the high values of the closing charge, the two densities are similar, reaching peaks at about the same value, but with lower probability for all of the lower values in the case of the higher credit score. All of the difference is at the upper end, where the base case has much more probability above $\tau=\$ 7,000$. Apparently borrowers with better credit scores are able to avoid the mistake of agreeing to such high charges. FHA 


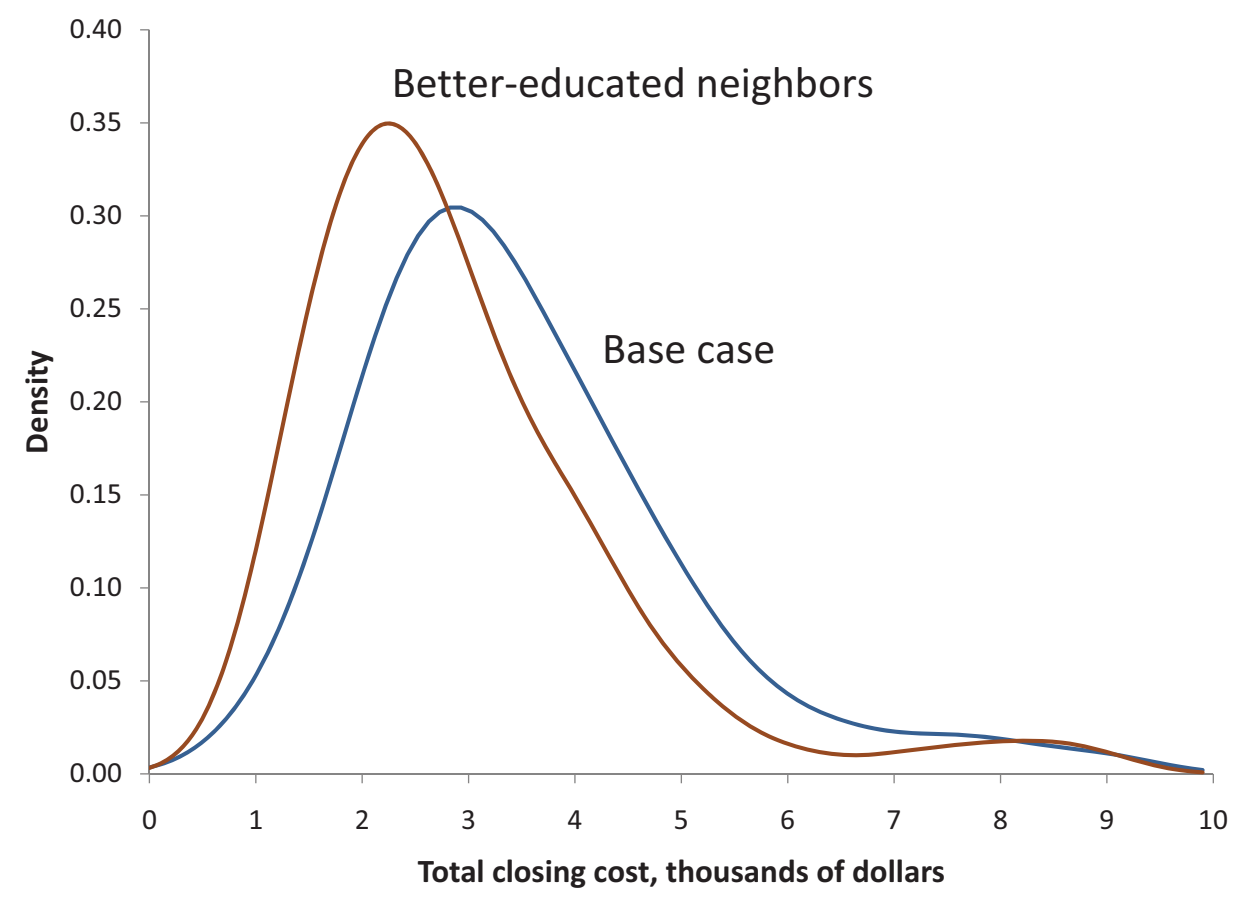

Figure 11: Smoothed Densities for the Base Case and for the Case of More Educated Neighbors

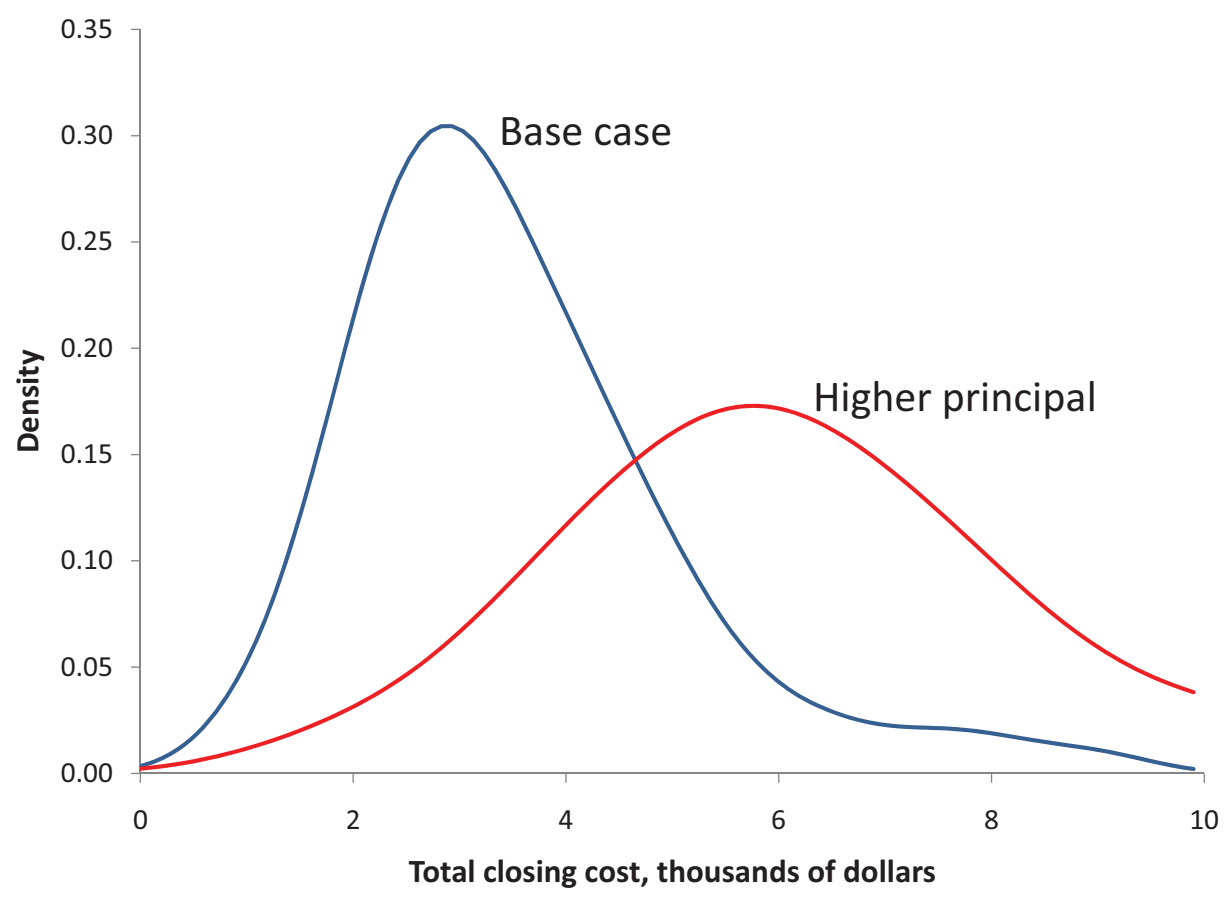

Figure 12: Smoothed Densities for the Base Case and for the Case of a Higher Principal 


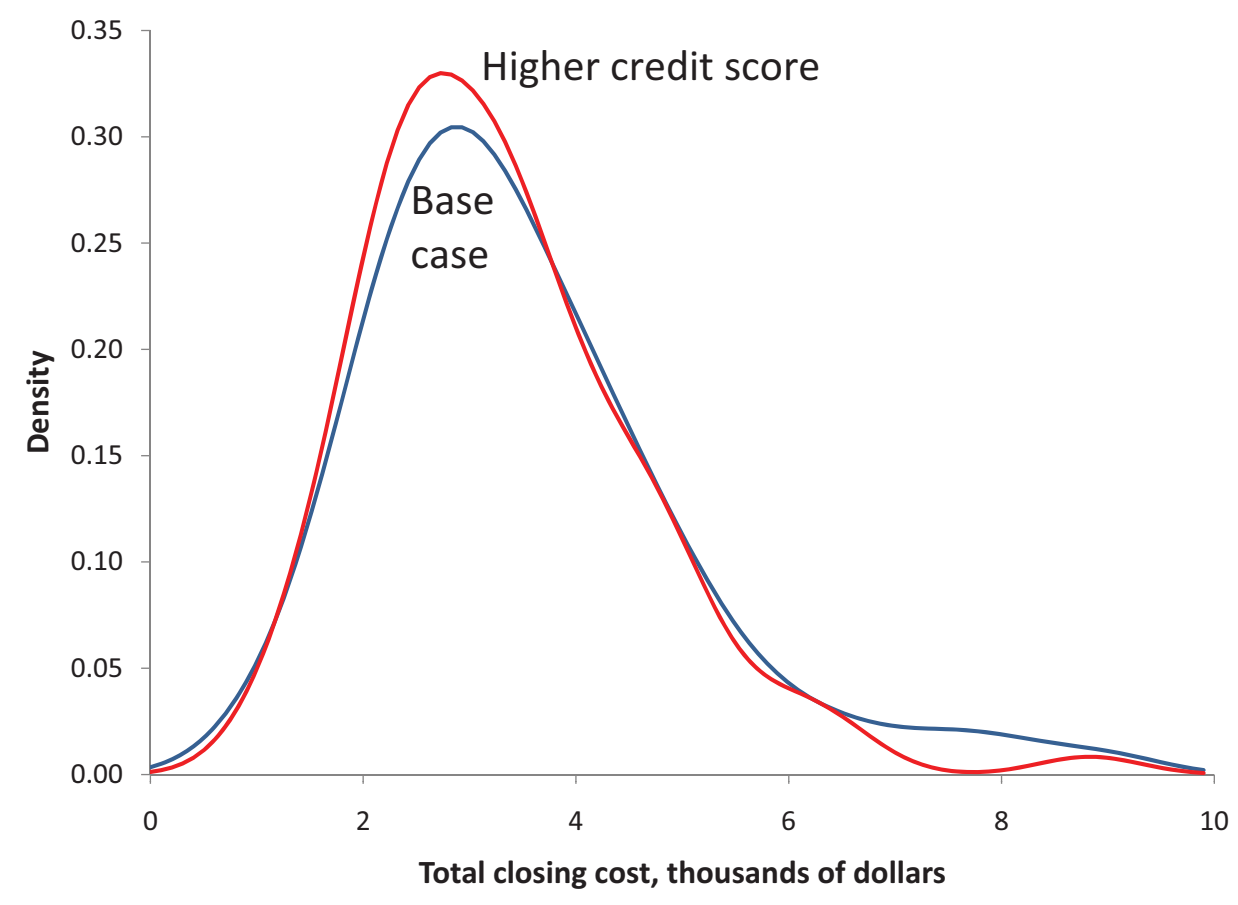

Figure 13: Smoothed Densities for the Base Case and for the Case of a Higher Credit Score

underwriting works mainly with a cutoff credit score, which the base case satisfies. Perhaps borrowers with credit scores close to the minimum acceptable score are less willing to shop, because they do not realize that their scores are acceptable to all FHA lenders.

\section{Consumer Confusion}

We believe that our results reveal substantial consumer confusion, in the sense that the process of obtaining a mortgage through a broker results in many borrowers paying far more for the broker's origination services than they would if they better understood how to shop for a mortgage and if they understood that the broker was not doing their shopping for them. Our first approach to supporting this conclusion is to fit a suitable model of optimal shopping to our data and then observe that the payoff to more intensive shopping - specifically, the benefit of getting a quote from an additional broker - is far higher than seems reasonable. Borrowers behave as if it costs over $\$ 1,000$ to get a quote from another broker. Of course, we cannot rule out the alternative conclusion that shopping among brokers for the best deal has such a high psychic cost that the choice to limit shopping is a rational response to that high cost. 


\subsection{Modeling market equilibrium with rational shopping}

A recent literature considers the econometric problem of inferring shopping costs from market data. Hong and Shum (2006) and Hortaçsu and Syverson (2004) are notable contributions, and Moraga-González (2006) is a recent survey. This literature considers posted pricesconsumers visit stores and buy from the one with the best posted offering. We have not found any empirical model in that literature that would apply to the problem we consider here, even if we accepted the assumption of posted prices. Hong and Shum follow Burdett and Judd (1983) in assuming that all sellers have the same cost. That assumption is untenable in our data, because it implies that the common value of cost must be lower than the smallest observed price. We find a tiny fraction of prices that are only a few hundred dollars. We can only make sense out of the data under the assumption of fairly heterogeneous cost. In any case, the heterogeneity of broker effort in the origination process, where some borrowers provide all the needed documents in proper form when first asked, while others need extensive help in preparing the documents, seems to preclude any assumption of equal cost for all originations.

On the other hand, Hortaçsu and Syverson's 2004 study of mutual funds assumes heterogeneity in both seller product cost and buyer cost of search, the case we believe describes the mortgage market. Their results support the conclusion that consumers suffer confusion in their choices of mutual funds by failing to shop hard enough for a low expense ratio. But they use the market shares of sellers to identify the two distributions, along with the observed distribution of posted prices (in their case, of mutual funds). Their approach is suitable to a market where each seller posts the same price for all buyers. Mortgage brokers tailor their proposals to individual borrowers, so the assumption fails in our case. In addition, we lack data on origination volume by broker.

The assumption of posted prices seems out of place in the mortgage origination market. The essence of a posted price is a commitment not to consider a counteroffer from a customer. Posted prices make sense in Internet commerce, studied by Hong and Shum (2006) and many others, and in regulated mutual funds, studied by Hortaçsu and Syverson (2004). Mortgage brokers, mostly working as individuals or in small groups, have no technology to commit to a stated price. If a borrower turns down an offer and makes a plausible case in favor of a lower closing charge, the broker may well make a better offer rather than risk losing the business. For a discussion of this issue in the labor market, see Hall and Krueger (2010).

As far as we know, there are no similar papers on negotiated prices. The theoretical study closest to the problem that a borrower faces in the mortgage origination market is McAfee and McMillan (1988). That paper considers the optimal strategy for commercial procurement from suppliers with heterogeneous costs. The optimal mechanism induces potential suppliers to reveal their costs; the buyer continues to play the revelation game with additional potential 
suppliers until the benefit from adding another falls short of the cost of playing the game again.

We take a view that is a simplification of McAfee and McMillan (1988) suited to the case where the buyer is a borrower seeking origination services from a broker. Rather than inducing the revelation of cost, which would require a strong commitment to a sealed-bid second-price auction setup, we suppose that the borrower seeks initial quotes from $N$ brokers, uses the quotes to extract better proposals, until the process ends with one quote that no other broker is willing to beat. This process is an English or Vickrey or second-price auction. Modeling of markets based on these auctions is made easier by the fact that bidding behavior is non-strategic. By standard auction principles, the best ultimate bid is the reservation value (cost) of the second-lowest-cost bidder. Because the winning bidder does not reveal cost, the bidder is protected from opportunistic action by the borrower based on a departure from the McAfee-McMillan commitment, by making a counteroffer to that bidder at a charge lower than the second-lowest but above the winner's cost. We also believe that borrowers who get the best deals on mortgage origination actually do their shopping the way that we model the process.

Notice that we are making an assumption of commitment by the borrower to decline to engage in further bargaining with the sole remaining bidder once the second-place broker has dropped out. The borrower accepts the last offer from the winner rather than making a counteroffer. We believe this assumption is generally realistic and it has the further advantage of leading to a simple and clean way to interpret the observed distribution of closing charges.

In this view of shopping, there is all the difference in the world between shopping from a single broker and from two. The model holds that the broker can extract all of the surplus in a bargain with the borrower, where the borrower's outside option is to accept the runner-up bid. In the case of a single bid, the outside option is no mortgage, meaning that the broker can extract the entire surplus from the purchase of a house or the refinance of a mortgage. Because we have no way to measure that surplus, we consider only the cases of two or more bidding brokers.

Let $B(k)$ be the cumulative distribution of loan origination cost among brokers - the fraction of brokers whose cost is no greater than $k$. The closing charge $\tau$ is the cost level of the runner-up in the bidding for the business of a borrower. We let $H(\tau)$ be the cumulative distribution of the total origination charge $\tau$ among borrowers.

The relation between the two distributions is easy to derive. The probability that a random draw of broker's cost is greater than $\tau$ is $1-B(\tau)$. The probability that none of $N$ draws is as low as $\tau$ is $(1-B(\tau))^{N}$. The probability that one of $N$ draws is as low as $\tau$ is $N B(\tau)(1-B(\tau))^{N-1}$. The probability that two draws or more are as low as $\tau$ (that is, the 


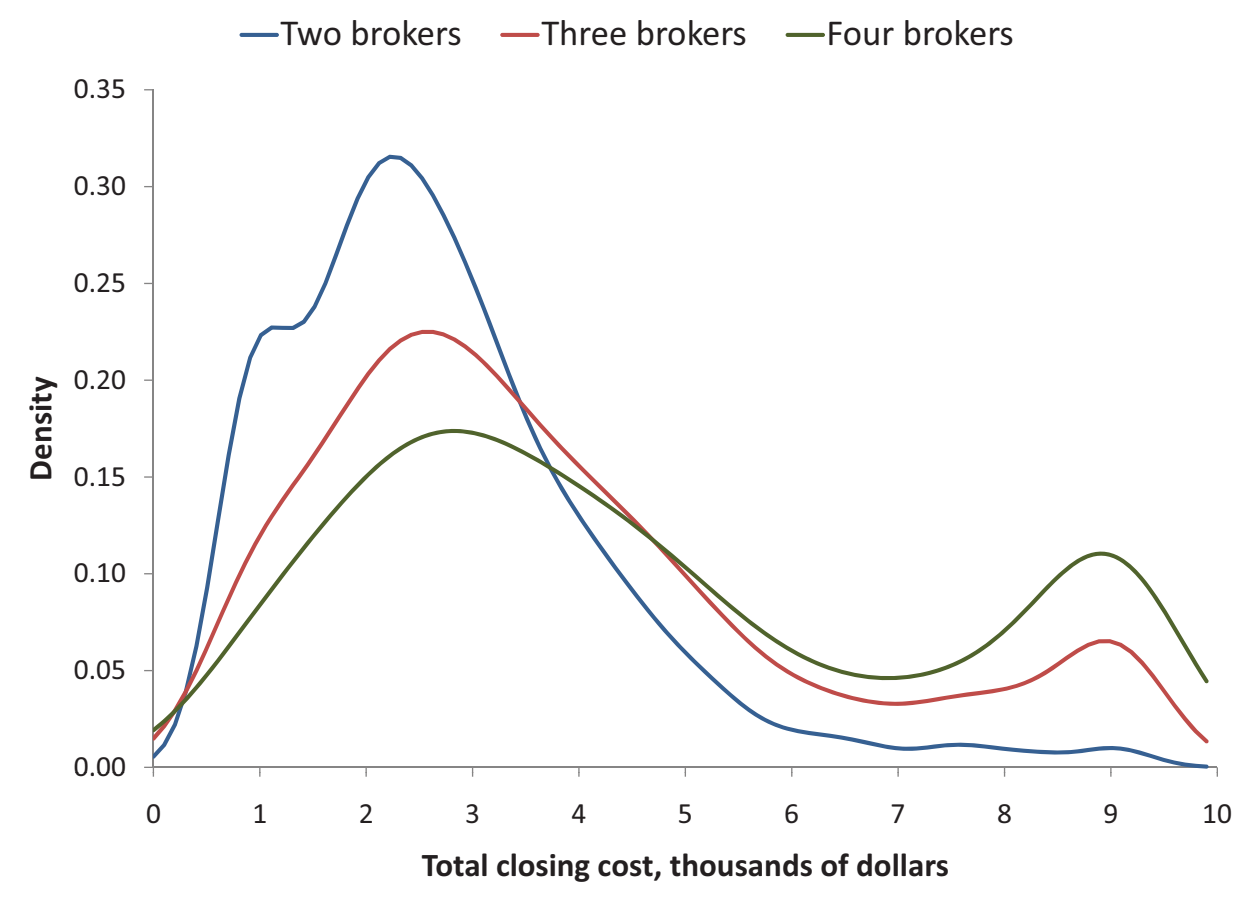

Figure 14: Distributions of Broker Cost Inferred from the Hypotheses that Borrowers Shop among 2, 3, and 4 Mortgage Brokers, Base Case

second-lowest draw is not greater than $\tau$ ) is one minus these two probabilities:

$$
H(\tau)=1-(1-B(\tau))^{N}-N B(\tau)(1-B(\tau))^{N-1} .
$$

We find the $B$ distribution in the following way: On a grid of values of $B$ in $[0,1]$, we evaluate the right-hand side of equation (8) and associate it with the value of $\tau$ where $H(\tau)$ is closest to that value. We take that value of $B$ and $k=\tau$ to be a point on the distribution of broker cost, $B(k)$. The set of values of $k$ that emerges from this process is a resampling of the original set of values of $\tau$ such that the values appear according to the distribution of broker cost rather than the original distribution of closing charges. Every borrower pays a charge that is equal to some broker's cost - that broker was the runner-up in the negotiation. That is why we relabel $\tau$ as $k$. We use a standard kernel smoothing density estimator on the resample to find the smoothed density of broker cost.

Figure 14 shows the distributions of broker cost for the cases where borrowers shop from $N=2,3$, and 4 brokers. Because more intensive shopping results in charges that are closer to cost, the distributions for higher numbers of brokers involve generally higher costs, so as to rationalize the same observed distribution of total charges. All of the distributions, including the one for the case of least intensive shopping from only two brokers, suggest that the implied level of cost is quite high for most mortgages and that the upper tail of cost includes completely implausible costs.

Figure 15 shows the implied distributions for the five cases in the case of shopping from 


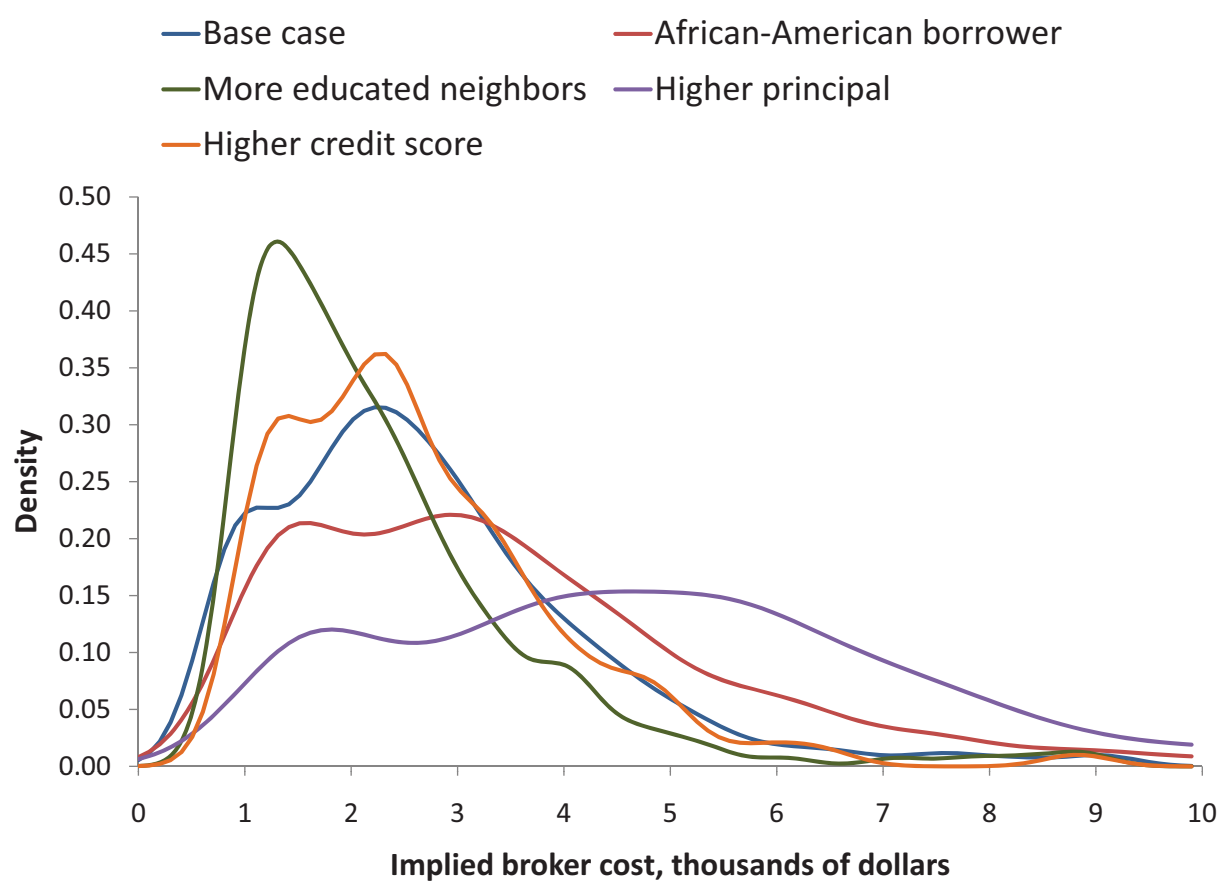

Figure 15: Distributions of Broker Cost Inferred from the Hypothesis that Borrowers shop from Two Brokers, for the Five Cases

only two brokers. The distribution for the high-principal loans lies far to the right - if it is true that borrowers only shop from two brokers, the cost of originating loans with principals of $\$ 200,000$ is far higher that that of smaller loans, a conclusion we find unlikely. The alternative interpretation is that borrowers seeking bigger loans often shop from only one broker, who is able to capture some part of the surplus that the borrower enjoys from buying the house, which will generally be larger for more expensive houses. A borrower dealing with only one broker faces an outside option in the bargain of not buying the house at all, while the shopper who knows to go to at least one other broker has the outside option of dealing with that broker. The tendency for consumers to leave more on the table for large transactions has been widely reported in the literature on consumer behavior.

\subsection{Benefits that borrowers failed to gain from more intensive shopping}

Our next step provides the main message of the paper - mortgage borrowers could save really a lot of money by shopping harder, from more brokers. Based on our results above on the distribution of cost among brokers, and on the survey evidence cited earlier in the paper, we conclude that few borrowers shop from more than two brokers and there are signs, such as the huge and implausible implied extra broker cost of high-principal mortgages, that borrowers often shop from only a single broker. 


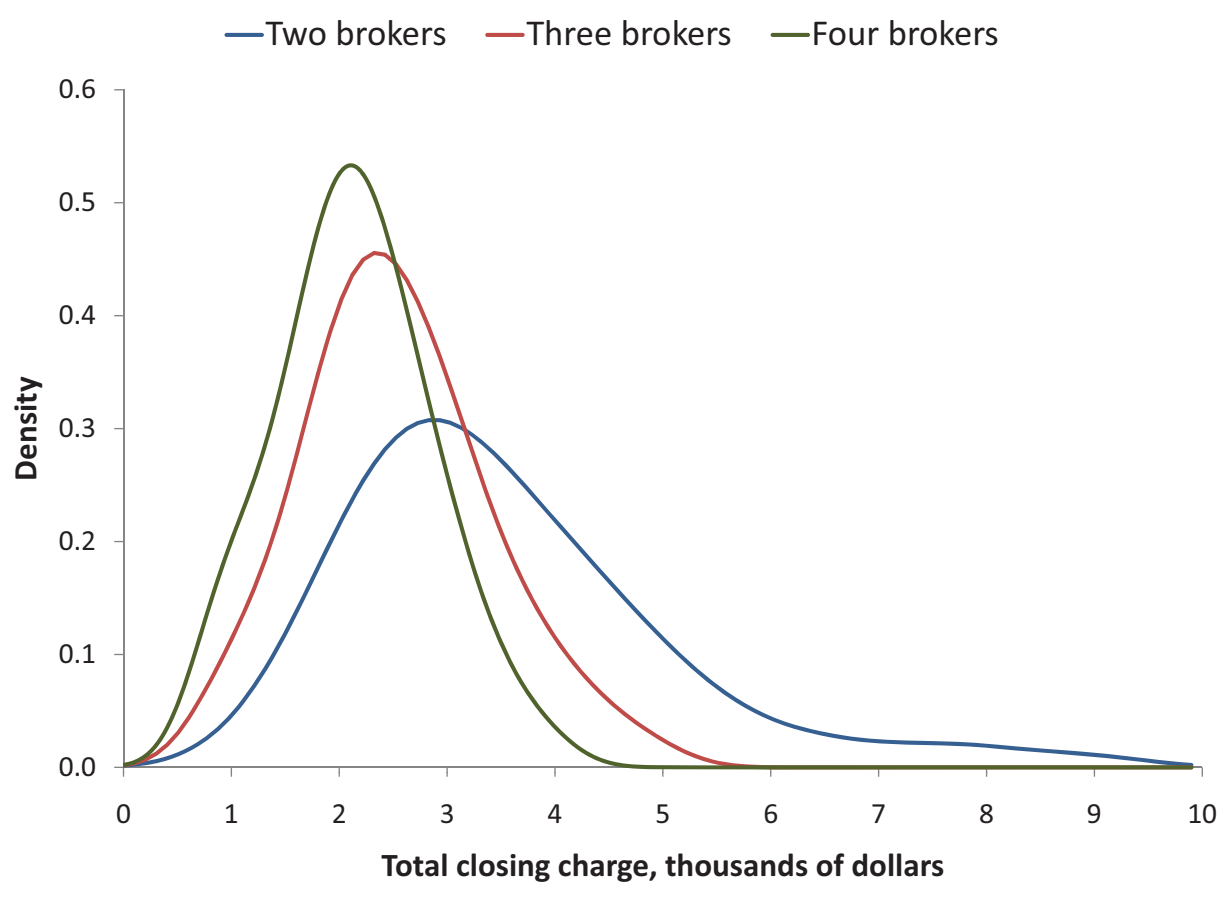

Figure 16: Distributions of Broker Charges Paid by a Base-Case Borrower Shopping from Two, Three, and Four Brokers, When the Distribution of Broker Cost is the One Inferred from the Hypothesis that Borrowers Shop from Only Two Brokers

If we had outside information about the distribution of costs among brokers, we could calculate the benefit of shopping from two, three, or four brokers (or even more), by solving for the distribution of second-lowest costs, on the assumption that a borrower ought to be able to bargain the lowest-cost broker down to the reservation price of the second-lowest one. Lacking such outside information, the best we can do is to take the implied broker cost distribution for two-broker shopping and calculate the better distributions of total closing charges that borrowers would pay if the shopped from three or four brokers. Figure 16 shows the results. It displays the distributions of the closing charges that a base-case borrower would pay, given the broker cost distribution inferred on the hypothesis that borrowers shop from only two brokers, for alternative shopping strategies involving shopping from two, three, and four brokers. The distributions shift substantially to the left for each added broker.

Table 6 shows the median gains that would be achieved from more intensive shopping, for the cases we have been considering. The gain from going to one additional broker ranges from $\$ 836$ for the white borrowers with smaller mortgages and high credit scores (who seem to shop more effectively than other groups, or who perhaps seem more savvy to brokers and consequently get better quotes from them) to a colossal $\$ 1,866$ for the borrowers seeking a high-principal loan. These gains rise to $\$ 1,197$ and $\$ 2,664$ for adding a fourth broker. We conclude that borrowers are failing to use a simple method to obtain better deals on their closing charges. While one might consider the possibility that most people are so averse to 


\begin{tabular}{|c|c|c|c|c|c|}
\hline & \multicolumn{5}{|c|}{ Case } \\
\hline & Base & $\begin{array}{l}\text { African- } \\
\text { American } \\
\text { borrower }\end{array}$ & $\begin{array}{c}\text { Highly } \\
\text { educated } \\
\text { neighbors }\end{array}$ & $\begin{array}{c}\text { High } \\
\text { principal }\end{array}$ & $\begin{array}{l}\text { High } \\
\text { credit } \\
\text { score }\end{array}$ \\
\hline $\begin{array}{l}\text { Mean gain from shopping from } \\
\text { one additional broker, dollars }\end{array}$ & $\begin{array}{l}971 \\
(32)\end{array}$ & $\begin{array}{l}1,260 \\
(84)\end{array}$ & $\begin{array}{l}893 \\
(69)\end{array}$ & $\begin{array}{l}1,842 \\
(109)\end{array}$ & $\begin{array}{l}841 \\
(50)\end{array}$ \\
\hline $\begin{array}{l}\text { Mean gain from shopping from } \\
\text { two additional brokers, dollars }\end{array}$ & $\begin{array}{c}1,377 \\
(42)\end{array}$ & $\begin{array}{l}1,815 \\
(120)\end{array}$ & $\begin{array}{c}1,221 \\
(93)\end{array}$ & $\begin{array}{l}2,626 \\
(143)\end{array}$ & $\begin{array}{l}1,200 \\
(73)\end{array}$ \\
\hline
\end{tabular}

Bootstrap standard errors in parentheses

Table 6: Median Reduction in Total Closing Charge by Shopping from Three or Four Brokers, given Broker Cost Distribution Corresponding to Shopping from Only Two Brokers, for the Five Cases

the bargaining process that they are knowingly over-paying their brokers, we believe that a lack of awareness of the advantage of more intensive shopping is a bigger part of the explanation. Brokers seem to have mastered the art of dissuading their customers from doing the kind of shopping that comes naturally for other expensive purchases.

\subsection{Distribution of the broker's margin}

Under our conclusion that mortgage customers shop from only two brokers, we can calculate the distribution of the broker's margin - the amount that borrowers leave on the table, in the sense that they pay more than the broker's reservation price, which is his cost. The margin is the difference between the actual charge, the cost of the broker with the higher of the two costs, and the broker's own cost, the lower of the two costs. The Appendix explains how we calculate this distribution. Figure 17 shows the distribution of the margin, along with the distributions of the broker's cost by loan, and the distribution of the total closing charge. Note that the distribution of broker cost by loan lies to the left of the distribution of cost by broker, shown in Figure 14, because the shopping process gives more business to the lower-cost brokers. The low-cost brokers appear more often among loans than their share of the broker population. The distribution of cost by loan is somewhat irregular in comparison to the other distributions shown in this paper, because the minimum function gives high weight to the shape of the distribution of cost for fairly low cost. The irregularity is a feature of the underlying data, not an artifact of our calculation process.

Note that the distribution of broker margin in Figure 17 is not terribly different from the exponential that Berndt et al. (2009) assume in their approach to measuring the distribution of broker cost. But they also assume that cost is normally distributed, an assumption less 


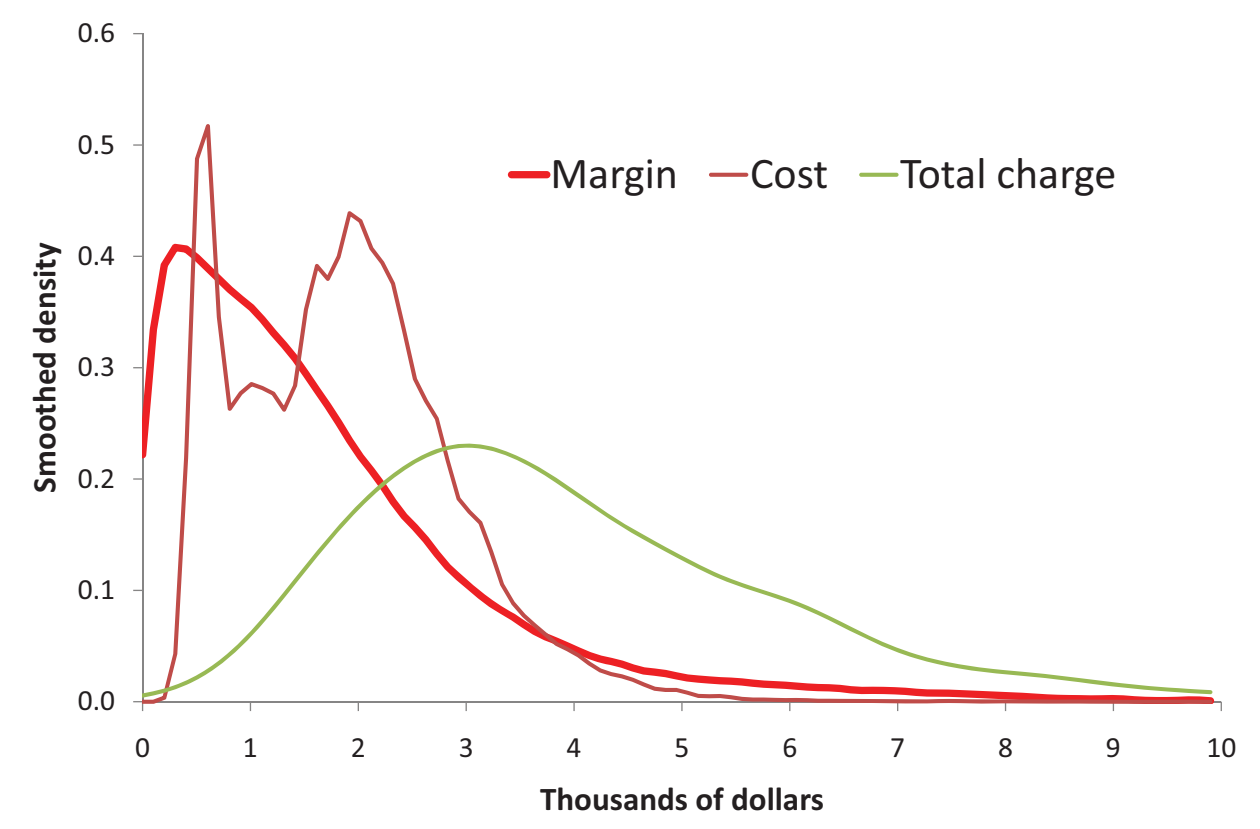

Figure 17: Distributions of Broker Margin, Broker Cost, and Total Closing Charge, by Loan

supported by our results. Of course, their approach has the advantage that it does not rest, as ours does, on a strong assumption about borrowers' shopping strategies.

\section{The Division of the Closing Charge between Cash and the YSP}

Earlier we noted that the function governing the YSP, as revealed in our data from actual rate sheets, has a shape that makes some borrower-broker pairs essentially indifferent between using the borrower's cash to pay the broker and borrowing the funds to pay the broker. Given that conclusion, we have studied the total payment. In this section, we explore the division of the total payment between the two sources.

We construct the variable $s=\frac{L}{L+Y}$ for each loan, the fraction of the total closing cost paid in cash. Thus a "no-cost" loan, where the broker receives only the YSP, has $s=0$, while a loan at the par coupon rate, with zero YSP, has $s=1$. Figure 18 shows the distribution of $s$ among the loans in the FHA sample. The modal loan's total closing cost is around half cash and half YSP. Loans with closing costs paid mostly in cash - the right side of the distribution - are relatively rare. Loans with closing costs paid mostly through the YSP are not common, but constitute an important minority.

Our earlier discussion of the choice of the division between cash and YSP suggests that there is a mapping between two characteristics of the borrower-her discount rate and the 


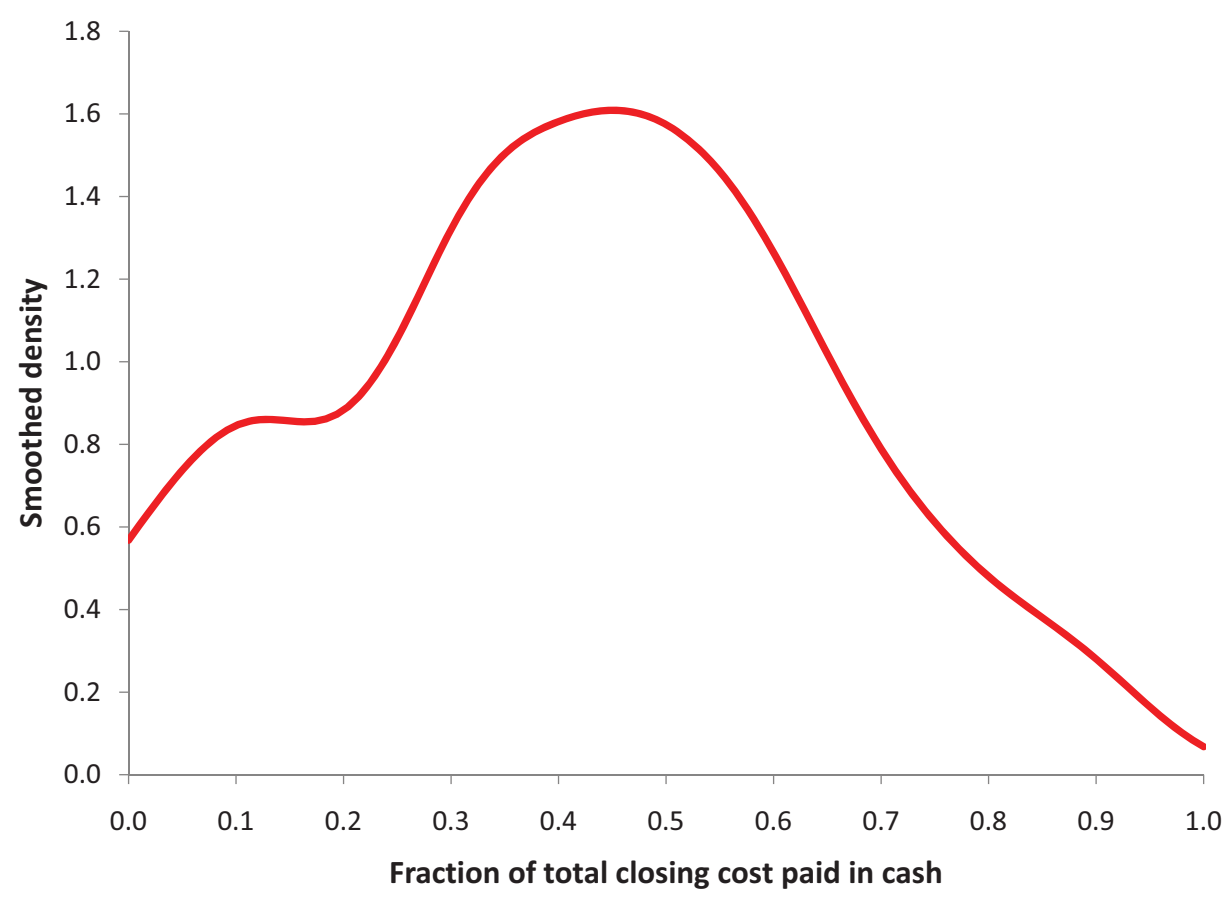

Figure 18: Smoothed Density of the Fraction of Total Closing Cost Paid in Cash

time she expects to keep the loan - and the division. Those with higher discount rates and lower keeping times opt for mostly YSP and vice versa. In that case, we can treat the observed value of the division, $s$, as a personal characteristic of the borrower. To pursue this idea, we divide the range of $s$ (the unit interval, aside from a few with negative cash or negative YSP, which are included in the first and last bins) into ten equal bins and introduce the corresponding ten dummy variables into our earlier estimation framework. We remove the constant, which is the sum of the dummy variables.

Table 7 shows the results for four estimating equations, stated as the implied values of the total closing cost at the 10th, 50th, and 90th percentile points and at the mean. The bottom estimate is for the mean and is estimated by regression. In general, borrowers who opt to fund their total closing costs mainly with the YSP, at the left edge of the table, pay less in total closing costs. Those who opt to pay with cash alone, at the right edge, pay less than those in the middle if they are below or at the median, but not if they are high payers, in the 90th percentile.

The estimates for the 10th percentile describe the relationship between $s$ and the total closing charge $\tau$ among borrowers whose total closing charges are quite low compared to the majority - that is, 90 percent of the borrowers pay more than this group. That point occurs at the very low level of $\$ 1,366$ in total closing charges for those who relied almost entirely on the YSP to pay those charges. The 10th percentile occurs at about double that level of total payment in the more popular case where the borrower pays 30 to 40 percent of the total in cash and the rest from the YSP. The 10th percentile falls back to lower levels among 
Total Closing Cost in the Base Case, by Division between Cash and YSP, Dollars

Fraction of Total Closing Cost Paid in Cash

\begin{tabular}{|c|c|c|c|c|c|c|c|c|c|c|}
\hline Estimation & 0.0 to 0.1 & 0.1 to 0.2 & 0.2 to 0.3 & 0.3 to 0.4 & 0.4 to 0.5 & 0.5 to 0.6 & 0.6 to 0.7 & 0.7 to 0.8 & 0.8 to 0.9 & 0.9 to 1.0 \\
\hline $\begin{array}{l}\text { Quantile, 10th } \\
\text { percentile }\end{array}$ & $\begin{array}{l}1,366 \\
(171)\end{array}$ & $\begin{array}{l}1,825 \\
(219)\end{array}$ & $\begin{array}{c}2,116 \\
(79)\end{array}$ & $\begin{array}{l}2,636 \\
(147)\end{array}$ & $\begin{array}{l}2,369 \\
(151)\end{array}$ & $\begin{array}{l}2,120 \\
(105)\end{array}$ & $\begin{array}{c}2,082 \\
(91)\end{array}$ & $\begin{array}{l}1,884 \\
(116)\end{array}$ & $\begin{array}{l}1,682 \\
(286)\end{array}$ & $\begin{array}{l}1,063 \\
(518)\end{array}$ \\
\hline $\begin{array}{l}\text { Quantile, } \\
\text { median }\end{array}$ & $\begin{array}{c}2,393 \\
(88)\end{array}$ & $\begin{array}{c}2,594 \\
(83)\end{array}$ & $\begin{array}{l}3,186 \\
(107)\end{array}$ & $\begin{array}{c}3,837 \\
(90)\end{array}$ & $\begin{array}{l}3,515 \\
(101)\end{array}$ & $\begin{array}{l}3,436 \\
(115)\end{array}$ & $\begin{array}{l}3,793 \\
(338)\end{array}$ & $\begin{array}{l}3,895 \\
(402)\end{array}$ & $\begin{array}{l}3,375 \\
(451)\end{array}$ & $\begin{array}{l}2,827 \\
(506)\end{array}$ \\
\hline $\begin{array}{l}\text { Quantile, 90th } \\
\text { percentile }\end{array}$ & $\begin{array}{l}3,500 \\
(148)\end{array}$ & $\begin{array}{l}3,971 \\
(284)\end{array}$ & $\begin{array}{l}4,701 \\
(255)\end{array}$ & $\begin{array}{l}4,813 \\
(126)\end{array}$ & $\begin{array}{l}5,613 \\
(365)\end{array}$ & $\begin{array}{l}6,245 \\
(230)\end{array}$ & $\begin{array}{l}8,460 \\
(584)\end{array}$ & $\begin{array}{l}8,227 \\
(953)\end{array}$ & $\begin{array}{l}7,167 \\
(823)\end{array}$ & $\begin{array}{l}6,491 \\
(888)\end{array}$ \\
\hline $\begin{array}{l}\text { Regression, } \\
\text { mean }\end{array}$ & $\begin{array}{l}2,237 \\
(108)\end{array}$ & $\begin{array}{l}2,501 \\
(129)\end{array}$ & $\begin{array}{l}3,257 \\
(113)\end{array}$ & $\begin{array}{c}3,730 \\
(95)\end{array}$ & $\begin{array}{l}3,786 \\
(113)\end{array}$ & $\begin{array}{l}3,827 \\
(132)\end{array}$ & $\begin{array}{l}4,432 \\
(221)\end{array}$ & $\begin{array}{l}4,595 \\
(318)\end{array}$ & $\begin{array}{l}3,787 \\
(375)\end{array}$ & $\begin{array}{l}3,392 \\
(491)\end{array}$ \\
\hline
\end{tabular}

Bootstrap standard errors in parentheses

Table 7: Estimates of the Relation between the Division of Funding the Total Closing Cost between Cash and YSP and the Amount of the Total Closing Cost

those who rely mostly on cash, though observations in that category are sparse and make the decline statistically ambiguous.

The results for the typical borrower, viewed as the median (second set of estimates) or mean (fourth set of estimates), also show a substantial advantage for those choosing not to pay in cash or to pay only a small fraction in cash. The advantage of paying less than 10 percent in cash relative to the total closing charge paid by those using 30 to 40 percent cash is $\$ 1,444$ in the median and $\$ 1,493$ in the mean. But these borrowers with typical shopping prowess do not gain a similar advantage if they use all cash - at the median, they save around $\$ 1,010$ compared to borrowers who use a fairly even mix of cash and YSP.

The results for the least-successful shoppers, those at the 90th percentile for the total origination charge, show a huge advantage for the low-cash shopping strategy, though even the borrowers in the lowest-cash category pay a total closing charge at the high level of $\$ 3,500$, almost triple the level of the 10th percentile group. Unlike the other percentiles and the mean, in this group, the total closing payment keeps rising with the cash share up to 70 percent cash, where the total payment is $\$ 8,460$, an astronomical amount to pay for origination services for a $\$ 100,000$ mortgage.

We conclude that all borrowers who opt to rely on the YSP to fund their origination costs rather than paying a mixture of YSP and cash are likely to make better deals.

To interpret the findings in Table 7 , we consider a number of hypotheses:

- Baseline: The borrower has a given $s$. The borrower and broker negotiate a total 
closing charge $\tau$ that is uncorrelated with $s$. The two components of the payment to the broker are the cash charge $L=s \tau$ and the YSP $Y=(1-s) \tau$.

- High-discount disadvantage: High-discount borrowers are more costly for the broker to serve and place lower value on the deferred payments to finance the yield-spread premium $Y$, so on both accounts the total origination charge $\tau$ is higher for the low$s$ borrowers who rely on the yield-spread premium to save themselves scarce current cash.

- Marginal home purchasers: Some borrowers are only barely able to manage the purchase of the house they are trying to finance. Not only are they short of cash to pay the broker, but they have hardly enough income to qualify for the loan. They need a low $s$ because of their cash shortage, but cannot qualify for much of a yield-spread premium. Because they have a credible threat not to complete the purchase, the broker is forced to offer a total closing charge $\tau$ close to his cost.

- Single-dimension shopping advantage: Borrowers who elect no-cost loans $(s=0)$ or those with low cash charges can shop for the lowest coupon rate without having to balance the cash charge against the coupon rate; they have no trouble determining the best deal among a set of proposed mortgages. Similarly, those who elect no yieldspread premium and thus to pay the par coupon rate can shop for the lowest cash charge. A third possibility for no-cost loans is that setting the broker's expectations that no cash will be paid by the borrower at closing precludes the broker from nibbling by adding on additional smaller fees, such as fax or courier fees.

The results refute the baseline hypothesis. Under that hypothesis, conditioning on the cash share $s$ would not change the distribution of the total origination charge $\tau$. Table 7 shows a strong tendency for the borrowers who contribute less cash, with low values of $s$, to pay substantially less by all four measures. The results plainly establish an interaction between $s$ and the total origination charge.

The results also refute the hypothesis of a high-discount disadvantage. The view seems plausible that these borrowers are more costly to serve, because the same factors that cause them to have high discounts also means that they have trouble finding the needed documents, filling out applications, and performing the other steps in the application process. Brokers probably do more hand-holding for high-discount borrowers. By definition, these borrowers place a lower discounted value on the future coupon payments that fund the yield-spread premium, another factor that would help the broker extract a high total closing charge. Our earlier analysis showed that high-discount borrowers will opt for low-s loans. High-discount borrowers will more often lack the cash to pay the broker up front. All of these plausible considerations point toward higher total broker charges for the low-s borrowers. But the 
evidence in Table 7 is that these borrowers pay thousands of dollars less than those with $s$ around 0.5 .

Table 7 supports the hypothesis that marginal home purchasers get better deals from their brokers. They benefit in the same way that the shabby buyer in the souk who turns his pockets inside out to show that he has only $\$ 3$ to buy the fez is likely to get the fez for that price, while a normal tourist can’t get it for less than $\$ 10$. The marginal home purchaser can't pay the broker much in cash and can't qualify for a mortgage with a high enough coupon to support much of a yield-spread premium, so the broker has the choice between doing origination for only a small profit or not doing it at all. The marginal home purchaser gets a low-price origination without shopping hard.

Finally, the results in Table 7 support the hypothesis that consumers shop better when the price has a single dimension. This hypothesis helps explain why the borrowers with high values of $s$ do somewhat better, as well as explaining the striking advantage of the more common single-dimension shopping strategy based on the no-cost loan. The borrowers with intermediate values of $s$ seem to respond to the cash and YSP elements of the total charge as if they had nothing to do with each other - at the 10th percentile, they pay $\$ 1,185$ for each element at $s=0.5$. Those who choose to pay only one component-either $Y$ or $L$ but not both-incur only half the total cost of those who pay with both. Borrowers behave as if they are unaware that incurring a higher YSP should entitle them to a lower cash payment.

We conclude that, among the four hypotheses, the data plainly support those relating to

marginal house purchasers and single-dimension shopping strategies, while the data refute the baseline hypothesis and the hypothesis of a disadvantage for high-discount borrowers.

\section{Concluding Remarks}

Untrained, inexperienced borrowers interact with specialist mortgage brokers in an important segment of the mortgage origination market. Brokers earn two kinds of compensation, explicit charges the borrower pays in cash at the closing and a commission the lender pays based on the spread between the coupon rate the borrower agrees to and the par mortgage interest rate. Both types of broker compensation seem to generate confusion. The fee to the broker at closing is not called "broker's fees" or anything like that. Rather, it is a confusing array of charges, each seeming to cover some aspect of origination costs, together with, in many cases, a charge for "points". Almost everybody, including regulators and many economists, seem to believe that points have a mechanical relation to a reduced interest rate, when in fact the term points is nothing more than another category for the broker's charge.

When interpreted in the context of a minimal amount of shopping among borrowers for broker services - shopping from a pair of brokers - the data support the proposition that 
a substantial fraction of borrowers would benefit substantially by shopping from additional brokers. The data also suggest that simplifying shopping by considering only loans where the broker receives all his compensation from the lender and the borrower pays no cash closing charge results in substantially better terms for borrowers. The borrowers who receive the worst terms tend to pay both large cash charges and to agree to high interest rates that give the broker large additional compensation in the form of the yield-spread premium.

Although brokers tend to make large margins over cost in each origination, we do not believe that they earn incomes above those available from other lines of work. Rather, they dissipate the margin by putting extra effort into getting in touch with prospective borrowers. Equilibrium in the broker origination market appears to be inefficient. If borrowers spent more effort getting in touch with more brokers - which is easy-brokers would earn less margin and would dissipate less effort trying to locate shy borrowers.

With respect to policy changes that might help achieve the more efficient equilibrium, we believe in evidence-based design. Disclosure law has historically been in the hands of lawyers, who design dense forms that may help absolve their clients of blame for consumer error, but which do little to help consumers find better deals. A new movement to design disclosures that are proven to be helpful, through field experiments, may result in some progress. We are inclined to believe that simple admonitions, such as "mortgage brokers are salesmen and the only way to get a good deal is to shop and bargain" and "you are more likely to get a good deal if you shop for no-cost loans" are more likely to yield improvements than, for example, trying to teach borrowers enough financial economics to understand the tradeoff between cash and the interest rate. 


\section{References}

Aguiar, Mark and Erik Hurst, "Life-Cycle Prices and Production," American Econmic Review, December 2007, pp. 1533-1559.

Ayres, Ian, Pervasive Prejudice? Unconventional Evidence of Race and Gender Discrimination, Chicago: University of Chicago Press, 2001.

and Peter Siegelman, "Race and Gender Discrimination in Bargaining for a New Car," American Econmic Review, June 1995, 85 (3), 304-321.

Becker, Gary, The Economics of Discrimination, Chicago: Univeersity of Chicago Press, 1957.

Berndt, Antje, Burton Hollifield, and Patrik Sandås, "The Role of Mortgage Brokers in the Subprime Crisis," December 2009. Carnegie-Mellon University.

Black, Harold A., Thomas P. Boehm, and Ramon P. DeGennaro, "Is There Discrimination in Mortgage Pricing? The Case of Overages," 2001. Working Paper 2001-4a. Atlanta, GA: Federal Reserve Bank of Atlanta.

Burdett, Kenneth and Kenneth L. Judd, "Equilibrium Price Dispersion," Econometrica, 1983, $51(4), 955-969$.

Busse, Meghan, Jorge Silva-Risso, and Florian Zettelmeyer, "\$1,000 Cash Back: The PassThrough of Auto Manufacturer Promotions," American Econmic Review, September 2006, 96 (4), 1253-1270.

Cohen, Mark A., "Imperfect Competition in Auto Lending: Subjective Markup, Racial Disparity, and Class Action Litigation"," 2006. Law and Economics Research Paper 07-01, Own Graduate School of Management, Vanderbilt University.

Courchane, Marsha and David Nickerson, "Discrimination Resulting from Overage Practices," Journal of Financial Services Research, 1997, 11, 133-151.

_ _ Brian Surette, and Peter Zorn, "Discrimination Resulting from Overage Practices," Journal of Real Estate Economics and Finance, 2003.

Federal Reserve Board, "Design and Testing of Truth-in-Lending Disclosures for Closed-end Mortgages," 2009. federalreserve.gov/newsevents/press/bcreg/bcreg20081218a7.pdf.

Hall, Robert E. and Alan B. Krueger, "Evidence on the Determinants of the Choice between Wage Posting and Wage Bargaining," May 2010. Hoover Institution, Stanford University. 
Hong, Han and Matthew Shum, "Using Price Distributions to Estimate Search Costs," The RAND Journal of Economics, 2006, 37 (2), 257-275.

Hortaçsu, Ali and Chad Syverson, "Product Differentiation, Search Costs, and Competition in the Mutual Fund Industry: A Case Study of S\&P 500 Index Funds," Quarterly Journal of Economics, 2004, 119 (2), 403-456.

Koenker, Roger and Kevin F. Hallock, "Quantile Regression," Journal of Economic Perspectives, Autumn 2001, 15 (4), 143-156.

Lacko, James and Janis Pappalardo, "Improving Consumer Mortgage Disclosures," 2007. Federal Trade Commission. ftc.gov/os/2007/06/ P025505Mortgage DisclosureReport.pdf.

LaCour-Little, Michael, "Discrimination in Mortgage Lending: A Critical Review of the IIterature," Journal of Real Estate Literature, 1999, 7, 15-49.

McAfee, R. Preston and John McMillan, "Search mechanisms," Journal of Economic Theory, 1988, 44 (1), 99-123.

Moraga-González, José Luis, "Estimation of Search Costs," March 2006. University of Groningen.

Scott-Morton, Fiona, Floden Zettelmeyer, and Jorge Silva-Risso, "Consumer Information and Discrimination: Does the Internet Affect the Pricing of New Casrs to Women and Minoritiesi," Quantitative Marketing and Economics, 2003, 1 (1), 65-92.

_ _ Florian Zettelmeyer, and Jorge Silva-Risso, "What Matters for Price Negotiation: Evidence from the U.S. Auto Retailing industry," 2007. Haas School of Business Working Paper.

Shroder, Mark D, "The Value of Sunshine Cure: The Efficacy of the Real Estate Settlement Procedures Act Disclosure Strategy," Cityscape: A Journal of Policy Development and Research, 2007, 9 (1), 73-92.

U.S. Census Department, "American Housing Survey," 2001. census.gov/hhes/ www/housing/ahs/ ahs01_2000wts/tab315.html.

Woodward, Susan E, "Consumer Confusion in the Mortgage Market," 2003. Sand Hill Econometrics Working Paper.

Woodward, Susan E., A Study of Closing Costs for FHA Mortgages, US Department of Housing and Urban Development, 2008. 


\section{Appendix (Not for publication)}

\section{A Earlier Research}

We review earlier research on mortgage closing charges, along with research on mortgage interest rates, non-real-estate consumer lending, and car-buying, that is relevant to this study. The auto and auto-lending markets are similar to the mortgage market in that transactions have large dollar values and prices are negotiated.

\section{A.1 Research on mortgage costs}

Woodward (2003) studied complete mortgage terms - loan rate plus lender/broker upfront charges, the YSP, and charges for other settlement services. She investigated the relation between the closing charges that borrowers pay directly and those they pay indirectly through the YSP, finding that a dollar of added YSP is associated with only a 55-cent decline in direct charges. This finding suggests that borrowers may not be aware that a higher mortgage interest rate puts cash in the broker's pocket that the borrower should be able to extract from the broker by insisting on a lower direct closing charge.

Another finding in Woodward's study was that borrowers who rolled all closing costs into the rate on their loan, by negotiating a direct charge of zero, paid total closing costs that were $\$ 1,500$ lower than those of other borrowers, other things equal. Borrowers who shop on rate alone may be financially more savvy than other borrowers, or may simply benefit from a shopping strategy that allows them to compare loans with only a single number, rate, and liberate themselves from attempting the rate-point trade-off.

Courchane and Nickerson (1997) studied the interest rates and the charges labeled as points, but not other cash charges, on loans from retail bank lenders. Direct lenders have internal rate sheets. Some borrowers are quoted a standard rate, and some are quoted from other cells having higher interest rates on the rate sheet. When a borrower pays an interest rate higher than the standard rate, the difference is called an "overage". Overages are economically equivalent to yield-spread premiums. Courchane and Nickerson find that minorities on average pay more in overages than do other borrowers. Studying a different set of lenders, Black, Boehm and DeGennaro (2001) also found that minorities pay higher overages. Neither of these studies has data on cash fees charged to borrowers, so they are not conclusive about loan terms for minorities. Woodward (2003), using data reporting both rate and closing fees, did find that minority borrowers pay more than other borrowers.

As we noted in the body of the paper, borrowers receive a disclosure form called a Good Faith Estimate (GFE) prior to committing to a mortgage. Shroder (2007) compared GFEs to the HUD-1 settlement statements giving the actual terms for 146 FHA loans. He found 
that most GFEs overestimate borrowers' ultimate cash closing charges by a small amount, but that for a minority, the GFE under-estimates by a large amount. He also finds that when lender/broker charges are higher, so are the charges for title services, a finding consistent with the findings in Woodward (2008) and Woodward (2003). He hypothesizes that this is consistent with the "sheep-shearing" view of the market: borrowers vulnerable to over-charge in one category are vulnerable in others also. The sheep can be sheared on both sides.

Shroder gave special attention to whether transactions showed evidence of uproar (divorce or unusual delinquency in property taxes) in transactors' lives. Such uproar could raise transaction costs by increasing the complexity of the transaction, raising the time pressure to get the deal closed, or reducing the seller's or buyer's resistance to agent opportunism. He found that transactions with indications of trouble had total lender or broker and title cash fees that were higher by $\$ 1,050$, other things equal, in a set where the average was $\$ 2,060$. He finds it implausible that a divorce or delinquent property taxes could so inflate transaction costs. He concludes that the present disclosure rules do not sufficiently improve the negotiating position of buyers and sellers relative to service providers to prevent personal difficulties from influencing the fees they pay. His evidence is less than conclusive because he did not include the charges labeled as points in his measure of closing costs.

Subprime mortgages are intended for borrowers with higher default risks; their higher interest rates compensate the lender for that risk. Courchane, Surette and Zorn (2003) find that a significant fraction of borrowers eligible for prime loans actually take out more expensive subprime loans. The authors find that the standard predictors of default-credit scores, assets, and load-to-value ratio - explain much of the difference in what type of loan borrowers get, but other factors also matter, including shopping behavior (do borrowers search for best rates and affordable monthly payments? Are they familiar with mortgage market terms?), adverse life events (divorce, illness, unemployment, large drop in income), channel (borrowers using brokers are more likely to get subprime loans than those who use lenders, other things equal), and age (older borrowers are more likely to have subprime loans, other things equal). After taking account of these factors, they found no meaningfully higher likelihood that minorities would take out subprime loans.

Minority borrowers' loan applications are rejected more often than are the applications of white borrowers. LaCour-Little (1999) reviews this literature. Higher rejection rates may be a factor in the reluctance of minority borrowers to shop aggressively for the best mortgage terms. Research on differences in rejection rates is inconclusive on the question of whether higher rates for minorities are the result of discrimination or a lower fraction of qualified borrowers among minority applicants for mortgages.

Cohen (2006), for car loans, and Woodward (2003), for mortgages, find that AfricanAmerican borrowers pay their loan brokers roughly $\$ 500$ more than do other borrowers. The differential for car loans is, of course, a much larger fraction of the amount of the loan. 
The race differences in broker closing charges result from some combination of taste-based pure racial discrimination, as described by Becker (1957), differences in costs of serving customers not reflected in explanatory variables but correlated with race, and differences in shopping behavior, possibly the result of racial differences in the way that shoppers are treated by mortgage brokers and direct lenders. Less effective shopping and higher rejection rates may arise from related sources.

\section{A.2 Findings from the Auto-Loan Market}

The institutional arrangements of the market for auto loans closely parallel those of the home mortgage market. Car buyers can get a loan from their local bank or credit union, or they can arrange financing at the point-of-sale with the auto dealer who sells them a car. The loan broker, usually a separate individual within a dealer's facility, operates with a rate sheet similar to the rate sheet of the mortgage broker, but simpler. Car lenders make finer distinctions on credit quality than do mortgage lenders. The car loan rate sheets generally have five credit-quality categories, with lower rates for better credit. As with the

mortgage rate sheet, the lender pays the dealer more for making loans at higher rates, and this amount is exactly analogous to a yield-spread premium. Cohen (2006) reports that on average, minority car buyers/borrowers agree to higher rates that result in additional payment from the wholesale lender to the car dealer of about $\$ 500$ per loan on new cars averaging $\$ 25,000$ in value. One feature of the auto loan market not found in the mortgage market is that wholesale auto lenders put a ceiling on the upward adjustment of interest rate for the two highest credit-quality buckets, but not for the lower-quality buckets. Cohen found that to evade these caps, auto loan brokers sometimes moved borrowers to a lower quality credit bucket than they merited (based on their credit scores) so as to quote them higher rates, which were sometimes accepted by the car buyers.

\section{A.3 Research Outside of Lending}

Beyond mortgage lending there is considerable research that can help interpret the findings in this study. In particular, the research on the purchase terms for cars, which are sold in markets where price is negotiated, is relevant. The relevant facts and principles found in this work, discussed in more detail below, are:

1. Education, income, comparison shopping, and tolerance for engaging in negotiation all have a measurable relation to prices consumers pay in markets for large purchases such as autos.

2. Minorities and women pay more for cars than do other consumers. Much, but not all, of the difference is related to education, income, and the willingness to comparison 
shop and negotiate.

3. Consumers capture a smaller share of the potential gains from trade when they do not know the size of the potential surplus.

Ayres and Siegelman (1995) found that minorities and women pay more for new cars than do white men. Scott-Morton, Zettelmeyer and Silva-Risso (2007) investigated the role of shopping strategy in these differentials. They find that success in shopping depends on knowledge of dealer invoice price, visits to additional dealers, patience, and taste or distaste for bargaining and shopping. The best deals arise from a combination of market knowledge and willingness to negotiate.

Scott-Morton, Zettelmeyer and Silva-Risso (2003) examined auto purchases on and off the internet. Offline, women pay 0.5 percent more and minorities an extra 2 percent $(\$ 500$ again), compared to white men, for equivalent cars. Sixty percent of this price differential for in-person shopping is related to income, education, already having a car (making search costs lower) and taste for shopping. For online car purchases, where customers also negotiate price, there are no race or sex differences in car prices.

Aguiar and Hurst (2007) demonstrate the general importance of shopping and comparing prices, in markets with posted prices, in their study of expenditure, consumption, and time spent shopping. At retirement, households spend more time shopping and find better prices.

Ayres (2001) explores four possible explanations for why minorities and women pay more for cars. The first two are Becker-type discrimination, involving a dislike of the buyer by the seller. Ayers leans against these sources of differential treatment because dealerships hire substantial numbers of minority salespeople and some dealerships are minority-owned, but nonetheless behave like other dealerships. He then considers the possibility that minority buyers might have more distaste for bargaining or be more inelastic demanders because they have less knowledge of market prices. The Scott-Morton et al. studies confirm both as sources of differential pricing.

Busse, Silva-Risso and Zettelmeyer (2006) study two different types of auto sales promotions. In one, a car maker offered car buyers a $\$ 1,000$ cash rebate. In another, the car maker offered $\$ 1,000$ to dealers who sell such a car. Standard economic analysis suggests that the two different promotions should have identical impacts on price paid and the number of cars sold. In fact, the two promotions had very different results. When the buyers collect the rebate, both buyer and car salesman know of the existence of the promotion. When the seller gets the bonus, only the sellers, not the car buyers, know of its existence. When car buyers get the rebate, consumers get 70 to 90 percent of the benefit of it - their total price net of the rebate is about $\$ 800$ lower than with no promotion. When car makers do a promotion to dealers, consumer benefit is only 30 to 40 percent of the surplus amount. The promotions direct to consumers were much more successful in selling additional cars than 
were the relatively concealed promotions to salesmen only.

The parallel between the auto dealer promotions and the mortgage market is that the lender payments to brokers are well understood by the mortgage brokers, but perhaps not by consumers. But the parallel is not perfect. An important difference is that the YSP is not a temporary promotion by lenders, but now a permanent part of how lenders distribute their wholesale terms to mortgage brokers. Despite the permanence of the wholesale arrangements, it seems that few consumers understand them.

\section{B Details of Shopping Calculations}

\section{B.1 Calculating smoothed densities from quantiles}

The standard kernel smoother, such as ksdensity in MatLab, takes a vector interpreted as a set of random draws from a distribution and returns the smoothed density of that distribution. Over a mesh $P_{i}=i / M$, the quantiles of the distribution $F(x)$, say $x_{i}$, with $F\left(x_{i}\right)=P_{i}$, can be interpreted as random draws from the distribution - they all have equal probability. Thus the application of the kernel smoother to $x_{i}$ yields the smoothed density of $x$.

\section{B.2 Inferring the distribution of broker cost}

Recall that

$$
H(\tau)=1-(1-B(\tau))^{N}-N B(\tau)(1-B(\tau))^{N-1} .
$$

Our approach to inverting this equation to find the distribution of broker cost $B$ given the distribution $H$ from our descriptive model is to find the quantiles $k(P)$ such that

$$
H(k(P))=1-(1-P)^{N}-N P(1-P)^{N-1} .
$$

The distribution $P=B(k)$ is the inverse of the quantile function $k(P)$.

\section{B.3 Inferring the distribution of broker margin}

Each borrower makes two independent draws of brokers, with costs $k_{i}$ and $k_{j}$. The winning broker's margin is $\left|k_{i}-k_{j}\right|$. For the $299^{2}$ combinations of the two, measured at the percentiles $k_{i}$ of the broker cost distribution for the base case, we compute the margin. We treat the resulting vector of margins as a set of independent draws with equal probability from pairs of brokers. We then apply the kernel smoother to that vector to find the smoothed density. We do the same for $\min \left(k_{i}, k_{j}\right)$ to find the distribution of the cost among loans. 


\section{B.4 Simulating outcomes for more intensive shopping}

Given the quantile function for broker cost, $k(P)$, we calculate the distribution, $H_{N}(\tau)$ of the second-lowest cost, $\tau$, for $N=3$ and $N=4$ from equation (10), taking $\tau=k(P)$. We invert $P=H_{N}(\tau)$ to get the quantile function $\tau_{N}(P)$. 